\title{
8. MOLECULAR AND ISOTOPIC COMPOSITIONS OF HYDROCARBONS AT SITE 533, DEEP SEA DRILLING PROJECT LEG $\mathbf{7 6}^{1}$
}

\author{
James M. Brooks, Leo A. Barnard, Denis A. Wiesenburg, ${ }^{2}$ and Mahlon C. Kennicutt II, Department of \\ Oceanography, Texas A\&M University, College Station, Texas \\ and \\ Keith A. Kvenvolden, U.S. Geological Survey, MS 99, Menlo Park, California
}

\begin{abstract}
In an investigation of gas hydrates in deep ocean sediments, gas samples from Deep Sea Drilling Project Site 533 on the Blake Outer Ridge in the northwest Atlantic were obtained for molecular and isotopic analyses. Gas samples were collected from the first successful deployment of a pressure core barrel (PCB) in a hydrate region. The pressure decline curves from two of the four PCB retrievals at in situ pressures suggested the presence of small amounts of gas hydrates. Compositional and isotopic measurements of gases from several points along the pressure decline curve indicated that (1) biogenic methane $\left(\delta^{13} \mathrm{C} \cong-68 \% ; C_{1} / C_{2} \cong 5000\right)$ was the dominant gas $(>90 \%)$; (2) little fractionation in the $C_{1} /$ $\mathrm{C}_{2}$ ratio or the $\mathrm{C}_{1}$ carbon isotopic composition occurred as gas hydrates decomposed during pressure decline experiments; (3) the percent of $\mathrm{C}_{3}, \mathrm{i}-\mathrm{C}_{4}$, and $\mathrm{CO}_{2}$ degassed increased as the pressure declined, indicating that these molecules may help stabilize the hydrate structure; (4) excess nitrogen was present during initial degassing; and (5) $C_{1} / C_{2}$ ratios and isotopic ratios of $\mathrm{C}_{1}$ gases were similar to those obtained from conventional core sampling. The PCB gas also contained trace amounts of saturated, acyclic, cyclic, and aromatic $\mathrm{C}_{5}-\mathrm{C}_{14}$ hydrocarbons, as well as alkenes and tetrahydrothiophenes. Gas from a decomposed specimen of gas hydrate had similar molecular and isotopic ratios to the PCB gas $\left(\delta^{13} \mathrm{C}\right.$ of $-68 \%$ or methane and a $C_{1} / C_{2}$ ratio of $\left.\sim 6000\right)$. Regular trends in the $\delta^{13} \mathrm{C}$ of methane $(\sim-95 \rightarrow-60 \%)$ and $C_{1} / C_{2}$ ratios $(\sim 25000 \rightarrow 2000)$ were observed with depth. Capillary gas chromatography $(G C)$ and total scanning fluorescence measurements of extracted organic material were characteristic of hydrocarbons dominated by a marine source, though significant amounts of perylene were also present.
\end{abstract}

\section{INTRODUCTION}

Hydrocarbons in marine sediments originate from either biogenic or thermogenic processes. Biological systems produce a wide variety of natural hydrocarbonsfor example, large quantities of methane $\left(C_{1}\right)$ produced by anaerobic bacteria and trace quantities of nonvolatile hydrocarbons (i.e., $n$ - $\mathrm{C}_{15}, n-\mathrm{C}_{17}$, pristane). Thermogenic hydrocarbons result from pyrolytic processes deep in the sedimentary column. The dominant thermogenic hydrocarbons are: saturated compounds with straight or branched (including isoprenoid) cyclic members that contain 1 to 50 (or more) carbon atoms; and aromatic compounds that contain 1 to 4 (or more) rings. In addition to hydrocarbons, anaerobic decomposition reactions mediated by denitrifying, iron-oxide reducing, sulfate reducing, and methanogenic bacteria in marine sediments result in the production of $\mathrm{N}_{2}, \mathrm{NH}_{3}, \mathrm{HS}^{-}, \mathrm{CO}_{2}, \mathrm{HCO}_{3}^{-}$, and other related compounds. Most of these terminal decomposition products are commonly observed as gas expansion pockets in DSDP cores of reducing sediments with high organic content (Edgar et al., 1973; Hunt, 1975; Bolli, Ryan, et al., 1978; Whelan and Hunt, 1978; Whelan, 1979; Whelan and Sato, 1980).

Differentiation between biogenic and thermogenic hydrocarbons is important in understanding petroleum

\footnotetext{
${ }^{1}$ Sheridan, R. E., Gradstein, F. M., et al., Init, Repts. DSDP, 76: Washington (U.S. Govt, Printing Office)

2 Present address (Wiesenburg): Biological and Chemical Oceanography Branch, Naval Ocean Research and Development Activity, NSTL Station, Mississippi.
}

formation, migration, and the origin of gases in subsurface sediments. A number of parameters have been suggested for differentiating hydrocarbon sources. Gaseous hydrocarbons of thermogenic origin generally contain significant concentrations of $\mathrm{C}_{2}-\mathrm{C}_{4}$ saturates. However, several investigators have suggested that the small amounts of ethane $\left(\mathrm{C}_{2}\right)$ and possibly propane $\left(\mathrm{C}_{3}\right)$ that generally accompany both biogenic and thermogenic methane may also be produced biologically (Whelan and Sato, 1979; Bernard et al., 1978; Oremland, 1981). Thermogenic hydrocarbons generally have $C_{1} /\left(C_{2}+\right.$ $\mathrm{C}_{3}$ ) ratios $<50$, whereas biogenic hydrocarbons have $C_{1} /\left(C_{2}+C_{3}\right)$ ratios > 1000 (Bernard et al., 1977, 1978; Brooks et al., 1979). Gases also can be characterized by their carbon isotopic composition (Bernard et al., 1977). The production of volatile hydrocarbons $\left(\mathrm{C}_{5}-\mathrm{C}_{15}\right)$ by biological processes is only speculative (Schwarzenbach et al., 1979; Sauer and Sackett, 1980). However, Whelan and Hunt $(1978,1980)$ and Whelan (1979) have identified a number of volatile alkanes, alkenes, cycloalkanes, furans, and sulfur-containing compounds of apparent biogenic origin in several DSDP cores.

\section{Gas Hydrates}

The principal objective of this work was an examination of gas from a region of suspected gas-hydrate occurrence. Gas hydrates are icelike clathrate structures in which gases are occluded within a crystalline water lattice under appropriate conditions of high pressure and low temperature. Hydrates exist in two forms. Structure I gas hydrates have a symmetrical shape and can include 
small molecules up to the size of $\mathrm{C}_{2}$. Structure II hydrates are slightly larger and have the ability to accommodate not only $C_{1}$ and $C_{2}$, but also $C_{3}$ and isobutane (i-C $C_{4}$ ) (Davidson et al., 1978). Molecules as large or larger than $n$-butane $\left(n-\mathrm{C}_{4}\right)$ cannot be included in either lattice type (Hitchon, 1974). The stability regions for gas hydrates in marine sediments are generally found in shelf regions with water depths greater than about 500 $\mathrm{m}$ and bottom-water temperatures near $0^{\circ} \mathrm{C}$. Although a wide range of molecules (e.g., $\mathrm{C}_{1}, \mathrm{CO}_{2}, \mathrm{~N}_{2}, \mathrm{O}_{2}, \mathrm{H}_{2} \mathrm{~S}$, $\mathrm{C}_{2} \rightarrow \mathrm{i}-\mathrm{C}_{4}$ hydrocarbons) can form gas hydrates, $\mathrm{C}_{1}$ and possibly $\mathrm{CO}_{2}$ are the only gases found in sufficient quantities to form gas hydrates in deep-sea sediments. Under the appropriate conditions $(T, P)$ for hydrate stability, gas concentrations have to exceed solubility levels at the in situ temperature and pressure before hydrates can form. Therefore, hydrates are only found in regions where there is significant biogenic methane production or where there is migration of thermogenic gases from deeper horizons. Thermogenic gases do not form hydrates at their site of production because the zone of hydrate stability is well above the temperatures necessary for their formation.

The presence of gas hydrates has been suspected in marine sediments for many years because laboratory studies have indicated that hydrates are stable at the conditions present along most of the continental slope, and because of the existence in some sediments of a bottom-simulating reflector (BSR). A BSR is an anomalous acoustic reflector that approximately parallels the bottom topography cutting across bedding planes and deepening with increasing water depth (Shipley et al., 1979). The BSR is thought to represent the lower boundary of gas hydrate stability, below which gas hydrates decompose due to increasing temperature with depth. The transition across the hydrated/nonhydrated interface would cause a sharp velocity gradient that could produce the BSR observed in seismic records. Kvenvolden and McMenamin (1980) and Kvenvolden and Barnard (in press) have summarized the inferred occurrence of gas hydrates in marine sediments. Gas hydrates appear to be common in the continental margins of all the world's oceans. However, gas hydrates were directly observed in marine sediments only by Yefremova and Zhizhchenko (1974) in shallow cores $(<10 \mathrm{~m})$ of the Black Sea, and by Moore, Watkins, et al. (1979) and von Huene, Aubouin, et al. (1980) during coring on DSDP Legs 66 and 67 in the Middle America Trench off Mexico and Guatemala.

Kvenvolden and Barnard (this volume) present geophysical and geochemical evidence for gas hydrates in the Blake Outer Ridge. Seismic evidence (based on the presence of a BSR) indicates that gas hydrates are widespread on the Blake Outer Ridge (Dillon et al., 1980; Markl et al., 1970; Shipley et al., 1979). DSDP Site 533 on the Blake Outer Ridge has a well-developed BSR and thus offered a high probability of successful gas-hydrate sampling. Previous drilling in this region on Leg 11 found sediments with high gas concentrations (DSDP Sites $102,103,104)$ capable of extruding the cores from the liners, although no obvious solid gas hydrates were observed. Nevertheless, Ewing and Hollister (1972) and Lancelot and Ewing (1972) postulated the presence of gas hydrates in these sediments. Thus Site 533 provided a unique research opportunity for the study of gas hydrates in marine sediments.

The principal tool for this study was the pressure core barrel (PCB) designed and developed by DSDP to retrieve sediment cores at in situ pressures, with the goal being the capture of intact gas hydrates. This device is especially useful in sampling gas hydrates, because the restricted pressure-temperature stability field of these structures (Kvenvolden and McMenamin, 1980) requires recovery of the sediments at nearly in situ conditions. A prototype PCB had been deployed unsuccessfully twice previously on Leg 44 , Site 388 , in an attempt to demonstrate the presence of gas hydrates in marine sediments (Kvenvolden et al., this volume). The Leg 76 work represents the first successful study of gas hydrates recovered using the PCB.

The main objective of this work was to characterize the gas distribution from the surface down the sediment column into a hydrate zone in order to:

1) verify conclusively the presence and nature of gas hydrates;

2) determine the gas sources for the natural gas hydrates as either biogenic or thermogenic;

3) determine if gases in the gas hydrate originate in situ or are upwardly migrating gases;

4) explore the conditions necessary and responsible for gas hydrate formation in deep ocean sediments; and

5) study the extent to which other gases, especially nitrogen and carbon dioxide, are present in natural gas hydrates.

\section{EXPERIMENTAL METHODS}

\section{Sampling}

Samples of gas from Site 533 were obtained from (1) the PCB, (2) a discrete sample of gas hydrate recovered from sediment, and (3) canned samples. Gas samples were extracted from the PCB through a high-pressure manifold with a regulator designed to attach directly to the sampling port of the PCB (Fig. 1). Samples were collected during pressure decline experiments in high-pressure, stainless-steel cyclinders. Additional aliquots were transferred from the cyclinders into $\sim 250$-ml evacuated aluminum samplers. All containers were either flushed with sample gas or evacuated before sampling. A detailed description of the PCB is found in Kvenvolden et al. (this volume). Samples from the discrete gas hydrate sample were collected from a specially fabricated sampling "bomb" (for details see Kvenvolden and Barnard, this volume). Canned sediment samples for headspace analysis were collected and processed by methods described previously (Bernard et al., 1978). Briefly, the technique involves sealing a $\sim 5-\mathrm{cm}$ long core section of wet sediment in a $0.5-1$ glass container holding $125-\mathrm{ml}$ of sodium-azide-poisoned, hydrocarbon-free seawater. The headspace was then flushed with helium through septa in the container top. The container was inverted, frozen, and returned to the laboratory for analysis.

\section{Gas Measurements}

Light hydrocarbons $\left(C_{1}-C_{5}\right)$ were determined using flame ionization gas chromatography (GC-FID, Hewlett-Packard 5710) with a 3-m, 1.5-mm-I.D. Porapak Q column at $70^{\circ} \mathrm{C}$ (Brooks et al., 1981). $\mathrm{CO}_{2}$ was determined with an O.I. Corporation Total Carbon System that measures the $\mathrm{CO}_{2}$ using a nondispersive infrared analyzer or by GC-TCD (Carle Model 8000) techniques with a Porapak Q column. Fixed gases (nitrogen, oxygen, and argon) were separated using a molecular seive column and determined using a Hewlett-Packard 5830A 


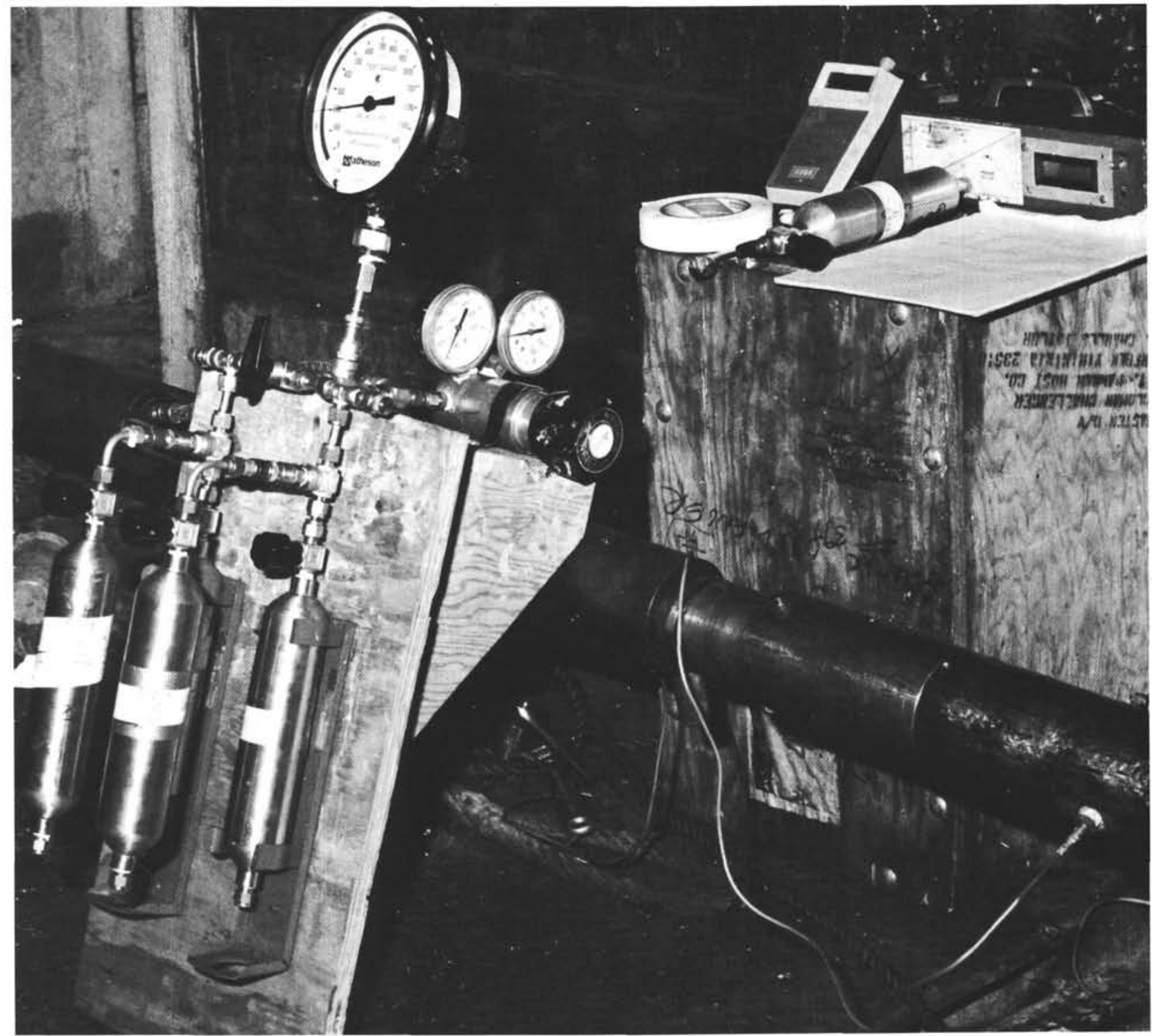

Figure 1. Manifold including high-pressure regulator, gauge, valves, and sampling cyclinders used to sample the PCB.

gas chromatograph equipped with a thermal conductivity detector (Wiesenburg, in press). An activated charcoal trap was used in the analysis stream to remove oxygen so that oxygen could be measured by the difference between $\mathrm{Ar}+\mathrm{O}_{2}$ and $\mathrm{Ar}$ only. Methane samples were prepared for carbon isotope analysis by combustion of several milliliters of methane to carbon dioxide at $800^{\circ} \mathrm{C}$. Isotopic values were determined using a dual collecting Nuclide Isotope Ratio Mass Spectrometer (Sackett et al., 1970).

\section{Volatile Organic Compounds}

Volatile organic compounds $\left(\mathrm{C}_{5}-\mathrm{C}_{15}\right)$ were analyzed by venting a known amount of gas contained in stainless steel cyclinders under pressure through a $0.5-\mathrm{cm}$ I.D. $\times 15-\mathrm{cm}$ column of solid polyphenyl ether absorbent (Tenax-GC) at a flow of $120 \mathrm{ml} / \mathrm{min}$. Tenax-GC has excellent retention characteristics for liquid hydrocarbons, retains very little water, and exhibits negligible column bleed at temperatures under $300^{\circ} \mathrm{C}$ (Butler and Burke, 1976). The volatile components trapped on the Tenax-GC were desorbed by heating $\left(250^{\circ} \mathrm{C}\right)$ with an on-line heating unit (Sauer, 1978). The components were transferred by helium flow to a liquid-nitrogen-cooled trap for sample consolidation (Fig. 2). This trap is attached to a 6-port sample valve that can be isolated and then heated in order to transfer the trapped hydrocarbons (using the GC carrier stream) onto a gas chromatographic column for sample separation and analysis. The separating column was a $0.3-\mathrm{cm}$ $\times 305$-cm stainless steel chromatographic column packed with $10 \%$ SP-2100 on $80 / 100$ Supelcoport, temperature programmed from $50^{\circ}$ to $180^{\circ} \mathrm{C}$. The eluted organic compounds were analyzed with a Hewlett-Packard $5830 \mathrm{~A}$ gas chromatograph using a flame ionization detector and with a Hewlett-Packard 5992 guadrapole gas chromatograph-mass spectrometer (GC-MS) using a jet separator. Mass spectra were recorded at a rate of $1 / 2.25 \mathrm{~s}$ from 33 to $250 \mathrm{amu}$ with an electron ionization source voltage of 1600 volts. Each spectrum was recorded using a Hewlett-Packard $9885 \mathrm{M} / \mathrm{S}$ flexible disk data system. Total ion chromatograms and selected ion monitoring was utilized. Mass spectra identifications were assisted by Heller and Milne (1978), the NIH-EPA-MSDC Mass Spectral Search System, the Eight Peak Index, and periodical literature.

\section{Sediment Analysis}

Canned sediment samples for headspace analysis were measured after the methods of Bernard et al. (1978). Briefly the glass containers were thawed, and the gases dissolved in the interstitial water were equilibrated with the helium gas phase of the headspace by agitation on a high-speed shaker. The headspace was then sampled and analyzed by syringe withdrawal of a l-ml aliquot. If concentrations were too low, the entire headspace was purged and trapped using the flow 
system shown in Figure 3. A flame ionization detector (HP 5710A GC) was used in conjunction with an electronic integrator (HP 3380) for the analysis of hydrocarbon concentrations. Carbon isotope ratios, sediment percentages of inorganic and organic carbon, and methane in interstitial water were determined following the method of Sackett et al. (1970).

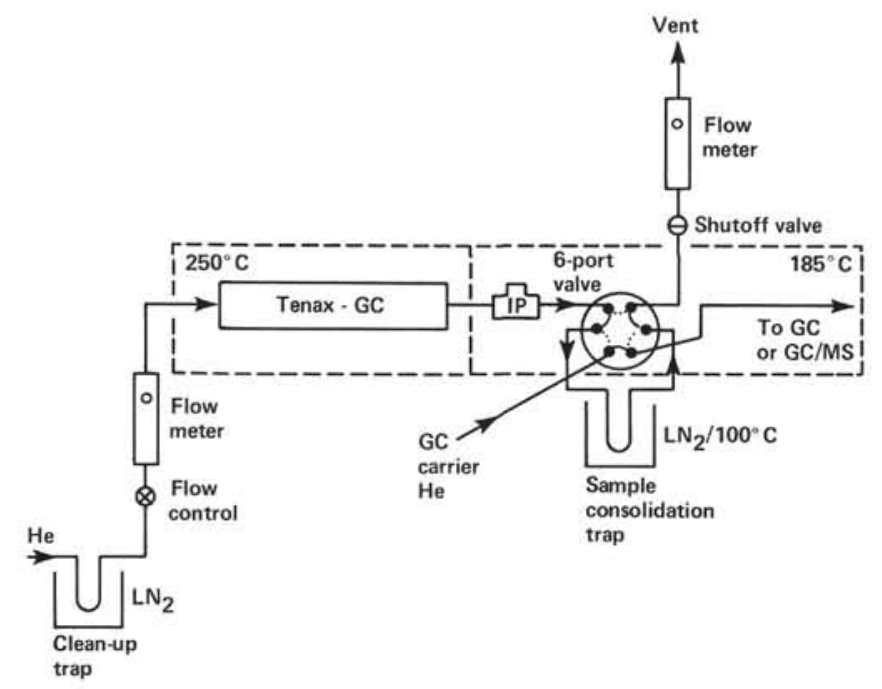

Figure 2. Schematic of the system used to collect and transfer volatile organic compounds to the gas chromatograph. $\left(\mathrm{LN}_{2}=\right.$ liquid nitrogen, IP = injection port, GC = gas chromatograph, GC/MS = gas chromatograph/mass spectrometer.)

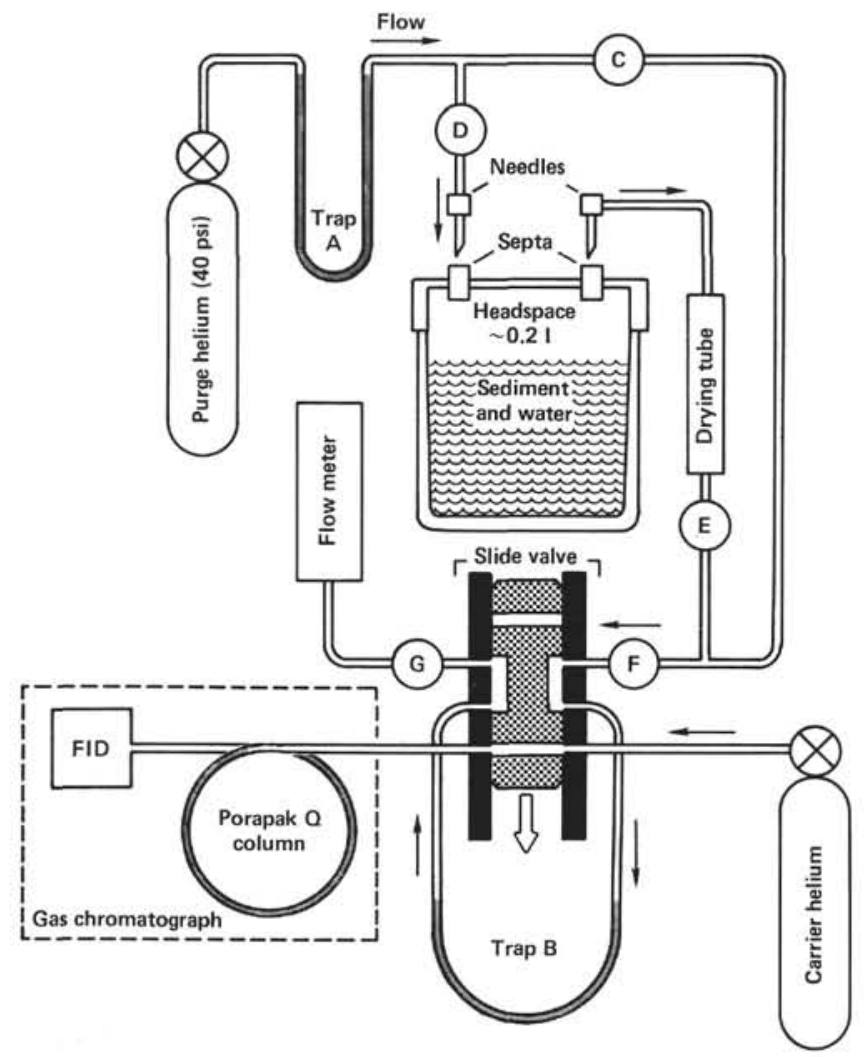

Figure 3. Schematic of the system used for analysis of sediment light hydrocarbons (Bernard et al., 1978). (FID = flame ionization detector; letters in circles are valve designators.)
For total scanning fluorescence spectra, $10 \mathrm{~g}$ of freeze-dried sediment were Soxhlet extracted for $12 \mathrm{hr}$. with hexane (Burdick \& Jackson Laboratories, Inc; Spectrometry-Nanograde), rotoevaporated to $10 \mathrm{ml}$, and stored in organic-free vials with Teflon lids. A PerkinElmer 650-40 Fluorometer with Perkin-Elmer 3600 Data Station was used to obtain 3-dimensional plots of emission, excitation, and intensity. The emission spectrum was obtained by scanning the emission monochromator at a fixed excitation wavelength, and the excitation spectrum was acquired by monitoring a fixed emission wavelength and scanning the excitation monochromator. The total fluorescence excitation wavelength-emission wavelength array was filled for each sample by sequential stepping of the excitation monochromator and scanning the emission monochromator over the wavelength range of interest. Intensity data were acquired during each emission scan at preset wavelength intervals. After acquisition and storage, the data were transformed via a three-dimensional rotation and hidden line correction routine. After transformation, a high resolution Perkin Elmer graphics package was used to generate a plot. Capillary gas chromatography of the hexane extracts was performed using a Hewlett-Packard $5880 \mathrm{GC}$ (flame ionization detector) with a 50 -m fused silica column programmed from $80^{\circ}-280^{\circ} \mathrm{C}$ at $6^{\circ} \mathrm{C} / \mathrm{min}$.

\section{RESULTS AND DISCUSSION}

The high probability of gas hydrates at Site 533 led to the drilling of two holes at this site. Hole 533 was continuously cored to $168 \mathrm{~m}$ sub-bottom using a hydraulic piston core. Hole 533A was rotary cored from 143 to $399 \mathrm{~m}$. Gas samples for subsequent molecular and isotopic analysis were obtained from the $\mathrm{PCB}$, a discrete hydrate sample, and canned sediment samples.

\section{Pressure Core Barrel (PCB)}

The PCB at Site 533 was used to obtain sediment samples at in situ pressures. It was deployed five times in $3184 \mathrm{~m}$ of water at sediment depths between 152 and $392 \mathrm{~m}$ where gas hydrates were suspected. Hole penetration was limited to $400 \mathrm{~m}$ because of constraints against penetrating the base of the zone of hydrate stability, which is indicated by the BSR. Table 1 summarizes the PCB samplings that are detailed by Kvenvolden et al. (this volume). Three of the cores (PCB-1, PCB-3, and PCB-5) were retrieved on deck at in situ pressures (average 30 million Pascals, MPa), whereas PCB-4 was retrieved with only $10.3 \mathrm{MPa}$ pressure, possibly because of a temporarily jammed pressure relief valve. PCB-1 contained a slurry of drilling fluids and cuttings rather than a sediment core and was degassed, but no samples were collected for further study. PCB-2 closed correctly but failed to retain in situ pressure because of a missing plug. PCB-3 and PCB-5 functioned properly, and gas samples were withdrawn at timed intervals. PCB-4 also

Table 1. Results from pressure core barrel sampling at Site 533, DSDP Leg 76.

\begin{tabular}{ccccccc}
\hline $\begin{array}{c}\text { PCB } \\
\text { No. }\end{array}$ & $\begin{array}{c}\text { Sediment } \\
\text { depth } \\
(\mathrm{m})\end{array}$ & $\begin{array}{c}\text { Amount } \\
\text { cored } \\
(\mathrm{m})\end{array}$ & $\begin{array}{c}\text { Pressure } \\
(\mathrm{MPa})\end{array}$ & $\begin{array}{c}\mathrm{C}_{1} / \mathrm{C}_{2} \\
(\text { avg.) }\end{array}$ & $\begin{array}{c}{ }^{13} \mathrm{\delta}_{1} \\
(\text { avg.) }\end{array}$ & $\begin{array}{c}\text { Sediment } \\
\delta^{13} \mathrm{C}_{1} \\
(\text { avg.) }\end{array}$ \\
\hline PCP-1 & 152 & 2.5 & 27.5 & n.d. & n.d. & -72 \\
PCB-2 & 247 & $1.6^{\mathrm{a}}$ & 0 & n.d. & n.d. & -68 \\
PCB-3 & 333 & 6.1 & 32.3 & 5600 & -66 & -64 \\
PCB-4 & 361 & 6.1 & 10.3 & 5200 & -64 & -64 \\
PCB-5 & 392 & 6.2 & 30.2 & 4100 & -69 & -66 \\
\hline
\end{tabular}

Note: $n$.d. indicates not determined.

a Unpressurized core. 
contained gas and was degassed into one cyclinder, immediately vented, opened, and inspected for the presence of gas hydrate solids. None were found.

Degassing experiments were conducted with PCB-1, PCB-3, and PCB-5, although no gas samples were obtained from PCB-1. The degassing experiments for PCB-3 and PCB-5 are depicted in Figure 4. The pressure relief curves obtained from the PCBs comprised up to 3 distinct intervals: (1) initial hydrostatic pressure loss; (2) gas hydrate decomposition; and (3) sediment degassing. Without a sediment-filled core in the PCB, the hydrostatic pressure drop upon initial venting should be the only pressure change observed, assuming only free gas is present. However, because the sediment within the PCB restricts free movement of gas in the core, a stepwise, sawtooth pattern was observed (e.g., PCB-3) as the core was vented, the vent was closed, and free gas increased the pressure again as it migrated through the core toward the sampling port. However, if hydrates are present in a core, Hunt (1979) suggested that interval pressure could be maintained as gas is intermittently vented, with the hydrates decomposing to maintain the internal pressure. This sawtooth pattern appeared in PCB-5 (Fig. 4) when the PCB pressure exhibited a plateau at $\sim 1 \mathrm{MPa}$ during about $2 \mathrm{hr}$. of intermittent degassing. Although not conclusive, the plateaus observed in both PCB-1 and PCB-5 (see Kvenvolden et al., this volume), along with visual observation of gas hydrates elsewhere, suggest the presence of small amounts of hydrates in these cores. The PCB-3 degassing curve (Fig. 4), where gas pressures never rebuilt to previous levels after degassing, may be indicative of a nonhydrate degassing curve. After all hydrates have decomposed, the pressure in the core rapidly falls as the sediments degas (Fig. 4, PCB-5).

Sampling times during degassing experiments are indicated on Figure 4. The released portions of these gas samples were analyzed at sea by gas chromatography, and the remaining gas was stored for detailed shorebased studies of molecular and isotopic compositions. Only PCB-5 was degassed at two temperatures $\left(15^{\circ}\right.$ and $25^{\circ} \mathrm{C}$ measured at a port at the upper end of the PCB). In both PCB-3 and PCB-5, pressures increased after each sample was collected. $\mathrm{C}_{1}$ was the dominant constituent vented from the PCB (Table 2), composing 76 to $96 \%$ of the gas mixtures from PCB-3 and over $95 \%$ of the gas from PCB-5. $\mathrm{C}_{2}$ concentrations were three orders of magnitude lower than methane. The $\mathrm{C}_{1} / \mathrm{C}_{2}$ ratios (Table 2) gave no indication of molecular fractionation of these gaseous hydrocarbons during pressure-decline sampling. The $\mathrm{C}_{1} / \mathrm{C}_{2}$ ratios compared favorably with ratios in gas pockets from the surrounding cores (Site 533 report, this volume). Carbon isotopic composition of the evolved $\mathrm{C}_{1}$ from both PCB-3 and PCB-5 (Table 2) did not change significantly during the four-hr. degassing period, and the $\delta^{13} \mathrm{C}$ values for $\mathrm{C}_{1}$ in the PCB gases were found to be quite similar to the isotopic composition of $\mathrm{C}_{1}$ collected from gas expansion cracks (Galimov and Kvenvolden, this volume) in the conventional rotary cores. Also, no isotopic differences were noted between PCB and canned headspace gas samples or the discrete sample of gas hydrate.

Comparison of phase diagrams for various gas hydrates reveals interesting relationships (Fig. 5). Pure $\mathrm{N}_{2}$ or $\mathrm{CO}_{2}$-hydrates are not likely to form initially under the conditions prevailing in Site 533 sediments where $C_{1}$
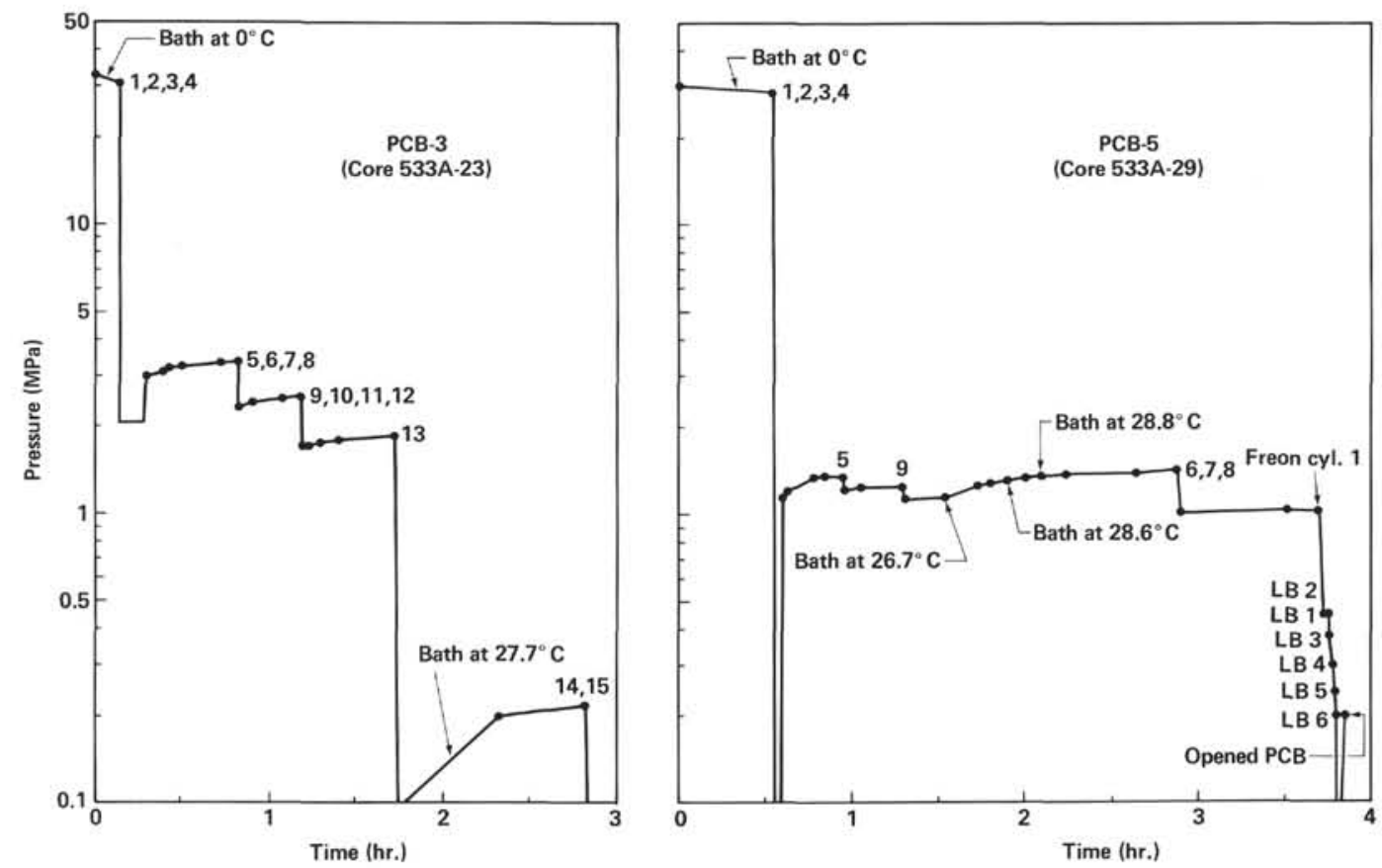

Figure 4. Pressure release curves from PCB-3 and PCB-5. (Pressure measurements and sampling locations are identified. Designators represent samples.) 
Table 2. Molecular and isotopic compositions of gas recovered from the pressurized core barrel, Hole $533 \mathrm{~A}$.

\begin{tabular}{|c|c|c|c|c|c|c|c|c|c|c|c|}
\hline $\begin{array}{l}\text { Core- } \\
\text { section }\end{array}$ & $\begin{array}{l}\text { PCB } \\
\text { no. }\end{array}$ & Aliquot & $\begin{array}{c}\text { Methane } \\
(\%)\end{array}$ & ${ }_{\delta}^{13} \mathrm{C}_{1}$ & $\begin{array}{l}\text { Ethane } \\
(\mathrm{ppm})\end{array}$ & $\begin{array}{l}\text { Propane } \\
\text { (ppm) }\end{array}$ & $\begin{array}{c}\text { i-butane } \\
(\mathrm{ppm})\end{array}$ & $\begin{array}{c}n \text {-butane } \\
(\mathrm{ppm})\end{array}$ & $\mathrm{C}_{1} / \mathrm{C}_{2}$ & $\begin{array}{l}\mathrm{CO}_{2} \\
(\%)\end{array}$ & $\begin{array}{c}\mathrm{N}_{2} \\
(\mathrm{ml} / \mathrm{l})\end{array}$ \\
\hline \multirow[t]{15}{*}{$3-3$} & \multirow[t]{15}{*}{3} & 1 & 76.0 & - & 10.2 & 4.2 & 1.8 & 0.5 & 7440 & - & - \\
\hline & & 2 & - & - & - & - & - & - & - & - & - \\
\hline & & 3 & - & -62.2 & - & - & - & - & - & - & - \\
\hline & & 4 & - & - & - & - & - & - & - & - & - \\
\hline & & 5 & 78.0 & -69.3 & 8.7 & 1.2 & 0.8 & 0.5 & 9040 & 0.10 & - \\
\hline & & 6 & - & -71.2 & - & - & - & - & - & - & - \\
\hline & & 7 & - & - & - & - & - & - & - & - & - \\
\hline & & 8 & - & -70.9 & - & - & - & - & - & - & - \\
\hline & & 9 & - & -70.4 & - & - & - & - & - & - & - \\
\hline & & 10 & - & -62.0 & - & - & - & - & - & - & - \\
\hline & & 11 & - & -68.4 & - & - & - & $=$ & - & - & - \\
\hline & & 12 & 96.1 & -68.5 & 171 & 58 & 1.9 & 0.7 & 5620 & 0.93 & - \\
\hline & & 13 & 94.5 & -66.5 & 143 & 9.7 & 1.5 & 0.5 & 6620 & 0.42 & - \\
\hline & & 14 & 90.2 & - & 179 & 9.7 & 3.0 & 0.6 & 5030 & 5.04 & - \\
\hline & & 15 & 90.4 & -68.3 & 181 & 8.5 & 4.5 & 1.0 & 5000 & 4.72 & - \\
\hline $26-5$ & 4 & 1 & 7.6 & -63.8 & 13.4 & 0.7 & 0.2 & 0.2 & 5670 & - & - \\
\hline \multirow[t]{16}{*}{$29-5$} & \multirow[t]{16}{*}{5} & 1 & - & -69.2 & - & - & - & - & - & - & 135 \\
\hline & & 2 & - & -68.1 & $=$ & $=$ & - & - & - & - & 91 \\
\hline & & 3 & 94.1 & -68.6 & 234 & 6.1 & 1.5 & 0.6 & 4020 & 0.16 & 77 \\
\hline & & 4 & - & -69.7 & - & - & - & - & - & - & - \\
\hline & & 5 & - & -67.5 & - & - & - & - & - & - & 3.5 \\
\hline & & 6 & - & -68.3 & - & - & - & - & - & - & 3.4 \\
\hline & & 7 & - & -70.6 & - & - & - & - & - & - & 4.0 \\
\hline & & 8 & $=$ & $\begin{array}{l}-68.3 \\
\end{array}$ & - & $=$ & - & - & - & - & - \\
\hline & & 9 & 97.0 & -68.5 & 242 & $\overline{8.0}$ & 1.6 & 0.7 & 4010 & 0.47 & 5.9 \\
\hline & & Freon 1 & 96.1 & $\begin{array}{l}-68.5 \\
-69.7\end{array}$ & 236 & $\begin{array}{l}0.0 \\
11.9\end{array}$ & 2.5 & 1.5 & 4060 & 1.77 & - \\
\hline & & LB-1 & 96.9 & -67.7 & 237 & 12.5 & 4.0 & 1.6 & 4090 & - & - \\
\hline & & LB -2 & - & -67.1 & - & - & - & - & - & - & - \\
\hline & & LB-3 & 93.9 & -66.7 & 230 & 15.7 & 4.5 & 2.0 & 4080 & 1.94 & - \\
\hline & & LB-4 & - & -69.7 & - & - & - & - & - & - & - \\
\hline & & LB-5 & - & -68.3 & - & - & - & - & - & - & - \\
\hline & & LB-6 & 93.8 & $\begin{array}{l}-68.5 \\
\end{array}$ & 223 & 18.5 & 5.5 & 2.4 & 4200 & 2.35 & 3.4 \\
\hline
\end{tabular}

Note: - indicates no data available.

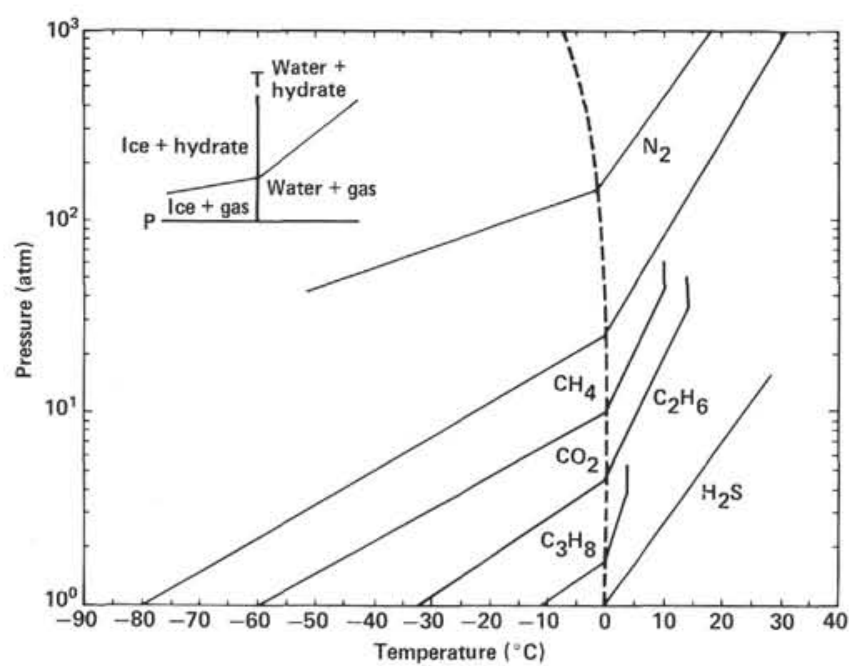

Figure 5. Phase diagrams for various gas hydrates.

is the dominant gas, and $\mathrm{CO}_{2}$ and $\mathrm{N}_{2}$ represent less than $10 \%$ of the gas mixture. However, $\mathrm{CO}_{2}$ and $\mathrm{N}_{2}$ can freely invade the $\mathrm{C}_{1}$ hydrate structure (Davidson, 1973). It is possible that, after formation of the $\mathrm{C}_{1}$ phase hydrate, $\mathrm{N}_{2}$ and $\mathrm{CO}_{2}$ are able to displace some $\mathrm{C}_{1}$ in the lattice of the existing hydrates forming both the thermodynamically more favorable $\mathrm{CO}_{2}$ hydrate and the less favored $\mathrm{N}_{2}$ hydrate.

In decomposition of the mixed $\left(\mathrm{C}_{1}+\mathrm{CO}_{2}+\mathrm{N}_{2}\right)$ hydrates, one would expect molecular or isotopic fractionation. The sequence of decomposition would be initial decomposition of any $\mathrm{N}_{2}$-containing hydrates, followed by the $\mathrm{C}_{1}$-containing hydrates, and finally by the $\mathrm{CO}_{2}$ - containing hydrates. Manifestation of this sequence of events is apparent in both the $\mathrm{N}_{2}$ and $\mathrm{CO}_{2}$ release curves (Fig. 6). During degassing of the sediments, an initial evolution of nitrogen was observed along with $C_{1}$ and $\mathrm{C}_{2}$. A possible explanation is that $\mathrm{N}_{2}$ is present as a help gas in some small fraction of gas hydrate in the sediments or as a trace amount of stabilized $\mathrm{N}_{2}$-hydrate. $\mathrm{CO}_{2}, \mathrm{C}_{3}$, and $\mathrm{C}_{4}$ concentrations (Fig. 6) increased in a regular fashion during the degassing period. $\mathrm{CO}_{2}$ concentrations increased about ten-fold during degassing. The rise in $\mathrm{CO}_{2}$ content of the evolved gas is believed to be due to the presence of trace $\mathrm{CO}_{2}$ hydrates in Site 533 sediments. The reason for the lack of $C_{1} / C_{2}$ fractionation is unknown. The large volume of $C_{1}$ present may mask any fractionation. Isotopic fractionation of the $C_{1}$ gas was not observed during the PCB sampling. The small mass difference between ${ }^{12} \mathrm{C}_{1}$ and ${ }^{13} \mathrm{C}_{1}$ compared to the large mass difference between $C_{1}$ and the other gases predicts little $\mathrm{C}_{1}$ isotopic fractionation relative to molecular fractionations between the other gases.

\section{Volatile Liquid Hydrocarbons and Heterocyclic Compounds}

A selected number of gas samples contained in the high-pressure, stainless-steel cyclinders obtained from the PCB were analyzed for volatile organic compounds. The volatile organic components determined ranged in boiling point from near $69^{\circ} \mathrm{C}$ ( $n$-hexane) to $270^{\circ} \mathrm{C}$ ( $n$-pentadecane). These samples were analyzed by GC-FID and GC/MS. A number of compounds were tentatively identified, including higher-molecular-weight hydrocarbons (e.g., $n$-alkanes, branched alkanes, cycloalkanes) and heterocyclic compounds (e.g., tetrahydrothiophenes). 

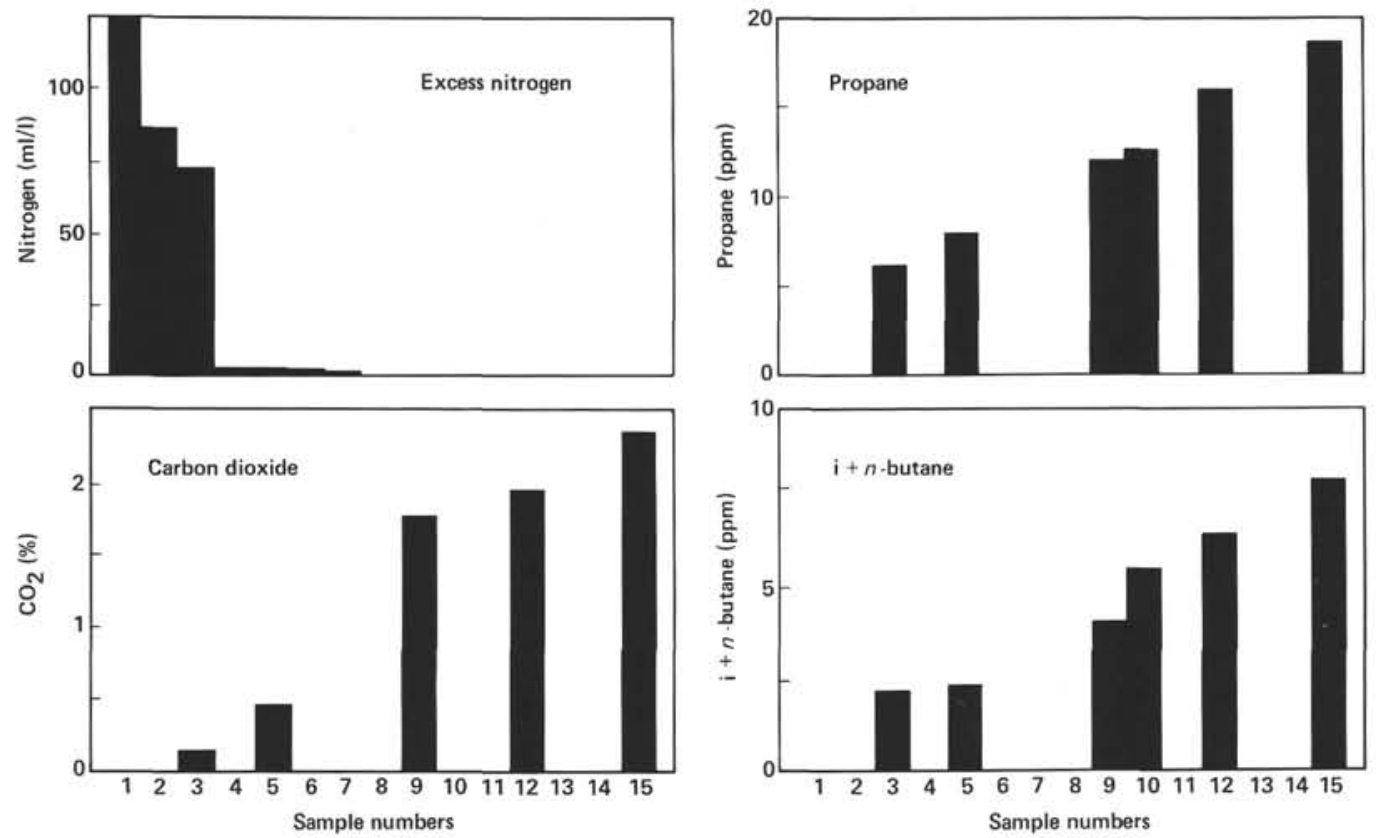

Figure 6. Composition of gas samples from Section 533A-29-5 (PCB-5) from sequential sampling during the pressure decline experiment.

Compounds identified are summarized in Table 3. Similar compounds have been reported at a number of DSDP sites (Edgar et al., 1973; Bolli et al., 1978; Hunt and Whelan, 1978; Whelan, 1979; Whelan and Sato, 1980).

The origin of $\mathrm{C}_{5}-\mathrm{C}_{15}$ compounds in DSDP derived gases has been an enigma. Generally there is neither sufficient temperature nor pressure to abiogenically produce these compounds in situ. These compounds often accompany what appears to be biogenic methane and have thus been associated with biological activity (Whelan and Sato, 1980; Hunt and Whelan, 1978; Whelan, 1979; Claypool, 1975; Whelan et al., 1980). Low-temperature chemical processes have also been hypothesized. A number of compounds in the $\mathrm{C}_{5}-\mathrm{C}_{15}$ range were detected in this study. A complete suite of $n$-alkanes $\left(\mathrm{C}_{5}-\mathrm{C}_{15}\right)$, branched alkanes, aromatics (benzene, toluene), and cycloalkanes (cyclopentane, cyclohexane, etc.) that were detected would infer a thermogenic source. A deeper thermogenic origin requires a movement up the sediment column from a deeper source. Whelan and Sato (1980) argue against this possibility due to the abrupt changes seen in the total concentrations and ratios of individual compounds. It has also been suggested that light hydrocarbon movement in finegrained sediments is minimal when small amounts of hydrocarbons are present at relatively shallow depth (Young and McIver, 1977). The needed quantitative data are not available in this present study to resolve the problem of the source of these compounds. It should be noted, however, that in general the concentrations of these compounds are very low and that the amount of thermogenic $C_{1}$ hypothetically associated with these higher-molecular-weight organic compounds may not be sufficient to significantly shift the isotopic composition of the biogenically produced $C_{1}$.
The compounds identified in Table 3 have been previously detected at other DSDP sites with a few exceptions (e.g., tetrahydrothiophenes). Normal alkanes in the range from pentane to pentadecane were detected. Generally only alkanes up to heptane have been previously reported. A number of branched alkanes were detected including methyl and dimethyl pentanes and higher-molecular-weight analogues. A few alkenes were tentatively identified, including a possible cyclohexene and a dimethyl heptene. The aromatic compounds were generally dominated by benzene and toluene. Whelan and Hunt (1980) consistently observed toluene as a major component in recent organic-matter-rich sediments and have shown that anaerobic bacteria can produce toluene from carotene. They conclude that toluene may have a bacterial source in some surface sediments.

The two heterocyclic compounds identified in this study have not, to our knowledge, been previously detected. Methyl and dimethyl tetrahydrothiophene were tentatively identified (Fig. 7) from our cyclinder gas samples from PCB-5. Whelan and Hunt (1980) have previously identified the unsaturated analogues of the mono-methyl compounds (thiophenes). The presence of thiophenes in ancient sediments and petroleum is well documented. The source and significance of these saturated analogues in these samples is unknown at this time.

\section{Hydrate Sample}

Although gas pockets were common in core sections deeper than $50 \mathrm{~m}$, and some frothing was present in a few core sections deeper than $152 \mathrm{~m}$, most of the hemipelagic sediments throughout the section remained semiconsolidated. The only visual evidence of gas hydrates was a single sample from $238 \mathrm{~m}$ sub-bottom depth in a 
Table 3. Volatile organic compounds identified in gas samples at Site 533.

\begin{tabular}{|c|c|}
\hline $\begin{array}{c}\text { Retention } \\
\text { time } \\
\text { (min.) }\end{array}$ & Tentative identification \\
\hline \multicolumn{2}{|c|}{ Section 533-29-5, PCB-5 (cylinder freon $1 / 650 \mathrm{ml}$ of gas) } \\
\hline 1.2 & Branched alkane (2-methylpropane) \\
\hline 1.3 & Butene or butane \\
\hline 1.8 & Isopentane \\
\hline 2.0 & Pentane \\
\hline 3.1 & Branched alkane (2-methylpentane or dimethylbutane) \\
\hline 3.4 & 3-methylpentane (tentative) \\
\hline 3.8 & Hexane \\
\hline 4.5 & Alkane, branched \\
\hline 4.6 & Methylcyclopentane \\
\hline 5.5 & Benzene \\
\hline 5.6 & trace cyclohexane \\
\hline 6.2 & Dimethylpentane \\
\hline 8.1 & Alkane, $n-\mathrm{C}_{7}$ (mixture) \\
\hline 12.0 & Toluene \\
\hline 15.5 & $\begin{array}{l}\text { Branched Alkane, } n-\mathrm{C}_{8}+\text { (1-methyl 3-ethyl, cyclopentane } \\
\text { or dimethylheptane) }\end{array}$ \\
\hline 16.5 & Branched alkane (ethylheptane?) \\
\hline 19.3 & $3,3,5$ trimethylcylohexane \\
\hline 27.3 & Mixture, $n-\mathrm{C}_{10}$ \\
\hline 32.1 & $n$-alkane $\left(n-C_{11}\right)$ \\
\hline \multicolumn{2}{|c|}{ Section 533-29-5, PCB-5 ( -11 of gas) } \\
\hline 0.3 & Butane \\
\hline 1.6 & Isopentane \\
\hline 1.7 & Pentane \\
\hline 2.1 & $\begin{array}{l}\text { Methylpentane } \\
\text { Hexane }\end{array}$ \\
\hline $\begin{array}{l}2.3 \\
2.5\end{array}$ & $\begin{array}{l}\text { Hexane } \\
\text { Methylcyclopentane }\end{array}$ \\
\hline 3.0 & Benzene \\
\hline 3.3 & Dimethylcyclopentane (tentative) \\
\hline 3.6 & Heptane \\
\hline 3.9 & Methylcyclohexane \\
\hline 4.7 & Octane (tentative) \\
\hline 5.2 & Toluene \\
\hline 8.3 & $\begin{array}{l}\text { 2-methyltetrahydrothiophene } \\
\text { Trimethylcyclohexene }\end{array}$ \\
\hline 9.4 & Trimethylcyclohexene \\
\hline 10.5 & Dimethyltetrahydrothiophene \\
\hline 14.1 & Nonane \\
\hline 17.1 & Decane \\
\hline 18.0 & $\begin{array}{l}n-C_{11} \\
n-C_{12}\end{array}$ \\
\hline $\begin{array}{r}19.9 \\
20.7\end{array}$ & $\begin{array}{l}n-C_{12} \\
n-C_{13}\end{array}$ \\
\hline $\begin{array}{l}20.7 \\
22.3\end{array}$ & $\begin{array}{l}n-\mathrm{C}_{13} \\
n-\mathrm{C}_{14}\end{array}$ \\
\hline 23.6 & $n-C_{15}$ \\
\hline \multicolumn{2}{|c|}{ Section 533-29-5, РCB-5 (cyclinders $1,2,3,5,6,7$ ) } \\
\hline 1.9 & Methylpentane \\
\hline 2.3 & Hexane \\
\hline 3.0 & Benzene \\
\hline 3.6 & Heptane \\
\hline 4.7 & $\begin{array}{l}\text { Unknown }(\mathrm{m} / \mathrm{z} 81) \text { (methylcyclohexene?) } \\
\text { Toluene }\end{array}$ \\
\hline $\begin{array}{l}5.1 \\
6.6\end{array}$ & $\begin{array}{l}\text { Toluene } \\
\text { Unknown }(\mathrm{m} / \mathrm{z} 94 ; 110)\end{array}$ \\
\hline 7.0 & Dimethylheptene (tentative) \\
\hline 9.5 & 2-methyltetrahydrothiophene \\
\hline 10.1 & Dimethyltetrahydrothiophene \\
\hline 14.1 & $n-\mathrm{C}_{9}$ \\
\hline 17.1 & $n-\mathrm{C}_{10}$ \\
\hline 18.4 & $\begin{array}{l}n-C_{11} \\
n-C_{11}\end{array}$ \\
\hline 19.4 & $\begin{array}{l}n-\mathrm{C}_{12} \\
n-\mathrm{C}_{13}\end{array}$ \\
\hline $\begin{array}{l}21.1 \\
22.4\end{array}$ & $\begin{array}{l}n-\mathrm{C}_{13} \\
n-\mathrm{C}_{14}\end{array}$ \\
\hline $\begin{array}{l}22.4 \\
23.6\end{array}$ & $\begin{array}{l}n-C_{14} \\
n-C_{15}\end{array}$ \\
\hline \multicolumn{2}{|c|}{ Section 533-3-3, PCB-3 ( 100 ml gas) } \\
\hline 1.9 & Methylpentane \\
\hline 2.4 & Methylcyclopentane \\
\hline 2.8 & Cycloalkane? (M.W. 84) \\
\hline 3.7 & Dimelthylcyclopentane \\
\hline $4.8,4.9$ & $\begin{array}{l}\text { Toluene }+ \text { alkane } \\
\text { Dimethylcyclohexane }\end{array}$ \\
\hline $\begin{array}{l}5.1 \\
5.7\end{array}$ & $\begin{array}{l}\text { Dimethylcyclohexane } \\
\text { Dimethylcyclohexane (tentative) }\end{array}$ \\
\hline 7.1 & Alkane? \\
\hline 8.0 & Trimethylcyclohexane (tentative) \\
\hline 8.9 & Xylene \\
\hline 10.0 & Trimethylcyclohexane \\
\hline 11.3 & Cycloalkane \\
\hline 12.9 & Cycloalkane \\
\hline 13.5 & Alkane \\
\hline 14.9 & Mesitylene \\
\hline 15.8 & Tetramethylcyclohexane \\
\hline 16.8 & $n-\mathrm{C}_{10}$ \\
\hline 19.1 & $n-C_{12}$ \\
\hline 20.5 & $n-\mathrm{C}_{13}$ \\
\hline 22.4 & $n-C_{14}$ \\
\hline 23.4 & $n-C_{15}$ \\
\hline
\end{tabular}

Note: $M \cdot$ W. $=$ molecular weight $; \mathrm{m} / \mathrm{z}=$ mass to charge ratio. layer of frothy sediments a few centimeters thick where layers of white crystals were observed when the core was split. Gas expansion measurements from this sediment sample gave gas:pore fluid ratios of $\sim 20: 1$, which were several times in excess of the amount of gas that could be in solution at the in situ pressure and temperature (see Kvenvolden and Barnard, this volume, for details of fluid ratios). Therefore this sediment sample must have contained a gas hydrate.

The carbon isotopic value for the methane in this hydrate sample was $-68.0 \%$, a value similar to that of a nearby headspace sample $(-66.9 \%$, Table 4$)$ and a core gas sample $(-69 \%$, Galimov and Kvenvolden, this volume). Molecular analysis on board indicated that $\mathrm{C}_{1}$ and $\mathrm{CO}_{2}$ composed 36 and $0.5 \%$ of the gas, respectively. The $\mathrm{C}_{2}, \mathrm{C}_{3}$, and i- $\mathrm{C}_{4}$ composed 123,2 , and $2 \mathrm{ppm}$ of the gas, respectively, whereas $n-\mathrm{C}_{4}, \mathrm{i}-\mathrm{C}_{5}$, and $n-\mathrm{C}_{5}$ only composed $0.06,0.15$, and $0.13 \mathrm{ppm}$, respectively. The remainder of the gas was atmospheric contamination. The distribution of $\mathrm{C}_{1}-\mathrm{C}_{5}$ hydrocarbons in the hydrated sample was considerably different from that of the surrounding gas pockets and headspace samples. The gas in these nonhydrate sediments did not show the sharp decrease in concentrations of molecules larger than $\mathrm{i}-\mathrm{C}_{4}$. The apparent exclusion of $n-\mathrm{C}_{4}, \mathrm{i}-\mathrm{C}_{5}$, and $n-\mathrm{C}_{5}$ is also evidence of hydrate, because gases larger than $\mathrm{i}-\mathrm{C}_{4}$ do not fit in the cages of either Structure I or II hydrates (Hand et al., 1974). Structure II hydrates must have been present in these samples, however. This structure would account for the presence of amounts of $\mathrm{C}_{3}$ and $\mathrm{i}-\mathrm{C}_{4}$ in the gas hydrate sample, because these gases cannot fit into Structure I hydrates. The absence of the abrupt drop-off in the gas concentration between $\mathrm{i}-\mathrm{C}_{4}$ and $n-C_{4}$ observed in gas from vacutainer and headspace samples suggests that the majority of the gas in the sediment section was not in hydrate form. Gas hydrate in sediments at Site 533 was apparently finely dispersed in thin, noncontiguous layers and not in the form of thick, massive hydrate zones that could act as a barrier to upward gas migration.

\section{Head-Space Analysis}

Twenty-four samples for headspace analysis were obtained from Holes 533 and 533A. Table 4 presents the $\mathrm{C}_{1} / \mathrm{C}_{2}$ and $\delta^{13} \mathrm{C}_{1}$ ratios. $\mathrm{C}_{1}$ is at least three orders of magnitude greater in concentration than $\mathrm{C}_{2}$. Accompanying the $C_{1}$ at Site 533 are small but significant concentrations of higher-molecular-weight hydrocarbon gases $\left(C_{2}-C_{5}\right)$ that tend to increase in abundance with depth (see Kvenvolden and Barnard, this volume). The $\mathrm{C}_{1} / \mathrm{C}_{2}$ ratios that average $>10,000$ in the top $200 \mathrm{~m}$ of sediment suggest that the gases are the result of biogenic processes. Between 200 and $400 \mathrm{~m}$, the $C_{1} / C_{2}$ ratios decrease to $<3000$, indicating the effect of early diagenesis or the contribution of thermogenic hydrocarbons from depth. The headspace $C_{1} / C_{2}$ ratios follow the same trend as the vacutainer samples from gas expansion cracks. However, the ratios are generally a few thousand lower than the ratios obtained from gas in vacutainer samples. This difference could result from loss or utilization of $C_{1}$ in the jars during storage or preferential migration of methane from the interstitial 
Spectrum no. 40.021 , sample no. 2 , retention time $=8.3 \mathrm{~min}$., scanned from 33 to $250 \mathrm{amu}$, no. of peaks detected $=109$,

base peak $=86.85$, base peak abundance $=779$, total abundance $=3524$

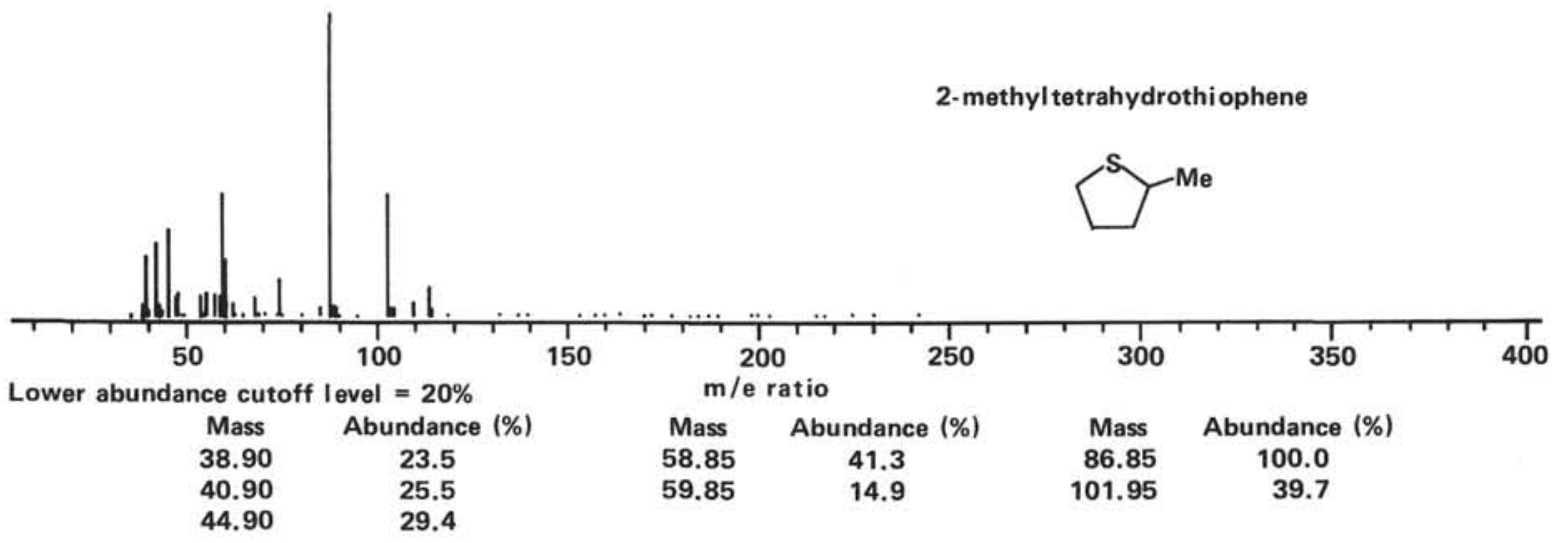

Spectrum no. 42.021, sample no. 2 , retention time $=9.4 \mathrm{~min}$., scanned from 33 to $250 \mathrm{amu}$, no. of peaks detected $=111$.

base peak $=108.90$, base peak abundance $=1891$, total abundance $=10643$

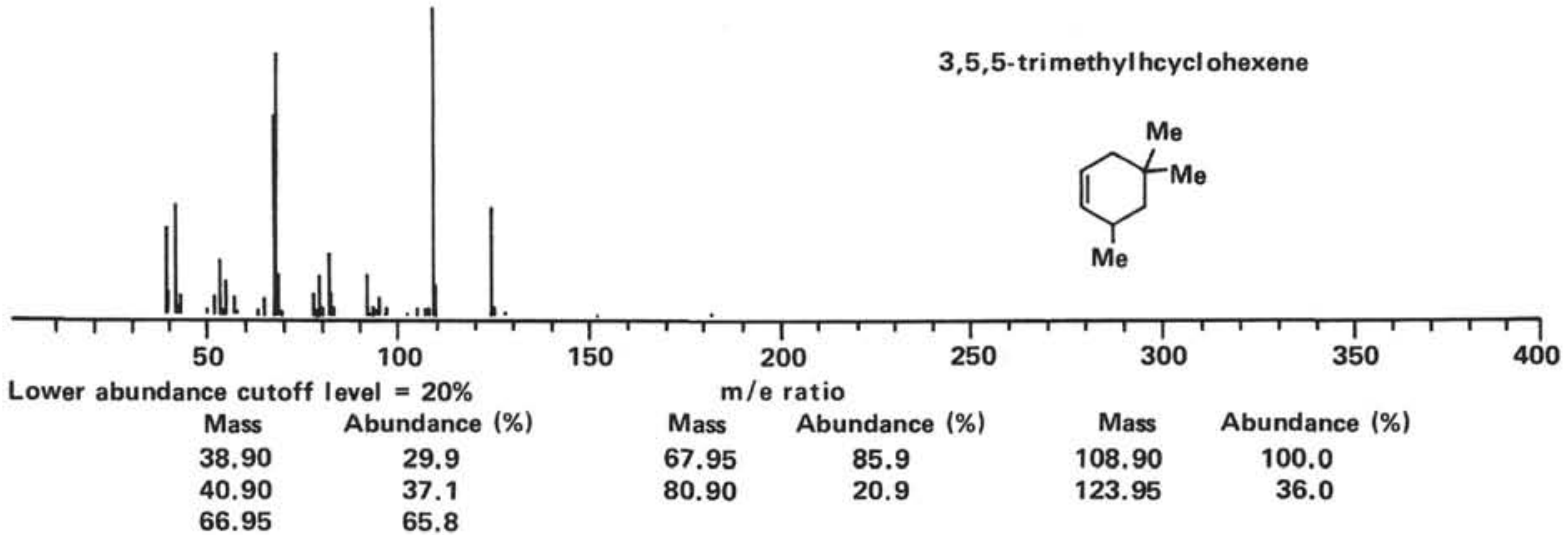

Spectrum no. 44.021 , sample no. 2 , retention time $=10.5 \mathrm{~min}$. ,

scanned from 33 to $250 \mathrm{amu}$, no. of peaks detected $=115$,

base peak $=100.95$, base peak abundance $=3759$, total abundance $=15507$

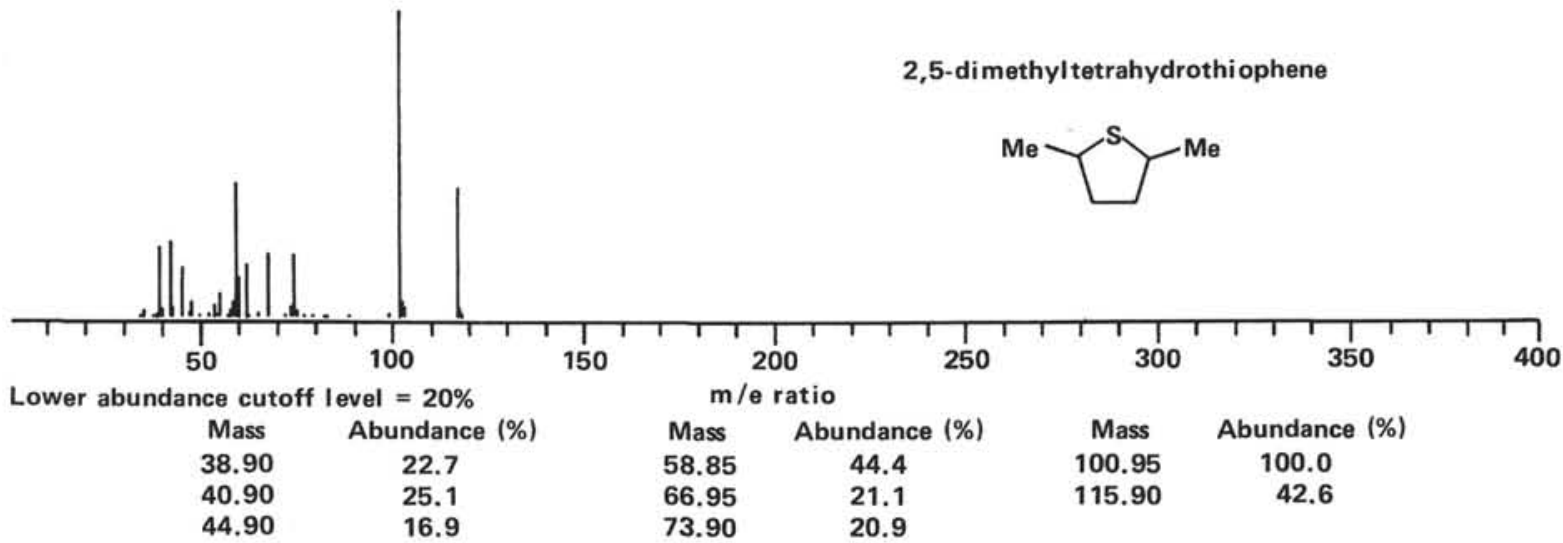

Figure 7. GC/MS spectra for three compounds tentatively identified in Section 533A-29-5-PCB-5 gas.

water into the expansion cracks of the core liner during pressure reduction. A plot of the $\mathrm{C}_{1} / \mathrm{C}_{2}$ ratios versus the $\delta^{13} \mathrm{C}_{1}$ is shown in Figure 8. The figure illustrates the general shift in both carbon isotopic and molecular ratios with depth.

Figure 9 shows the shifts in $C_{1}$ isotopic values with depth throughout the hole. Based on the biogenic-ther- mogenic model of Bernard et al. (1977), the $C_{1}$ throughout the hole is biogenic. However, there is a general trend from $-97.5 \%$ near the top of the core toward $-60 \%$ deeper in the section. At Site 533 there is not the almost linear trend with depth that Whelan (1979) observed at Site 397 . The greatest isotopic shift from -95.5 to $\sim-70 \%$ occurs in the upper $150 \mathrm{~m}$ of the sed- 
Table 4. Carbon components of Holes 533 and 533A sediments.

\begin{tabular}{|c|c|c|c|c|c|c|c|}
\hline $\begin{array}{l}\text { Core- } \\
\text { section }\end{array}$ & $\begin{array}{l}\text { Sub-bottom } \\
\text { depth } \\
\text { (m) }\end{array}$ & $\underset{(\%)}{\mathrm{CaCO}_{3}}$ & ${ }^{13} C_{\text {inorg. }}$ & $\begin{array}{c}\text { Org. } C \\
(\%)\end{array}$ & ${ }^{5}{ }^{13} \mathrm{C}_{\text {org. }}$ & $\mathrm{c}_{1} / \mathrm{C}_{2}$ & ${ }_{8}^{13} \mathrm{C}_{\mathrm{CH}_{4}}$ \\
\hline \multicolumn{8}{|l|}{ Hole 533} \\
\hline $\begin{array}{l}1-1 \\
5-1 \\
7-2 \\
9-2 \\
11-2 \\
13-2 \\
16-2 \\
20-1 \\
24-1 \\
28-2 \\
32-2 \\
37-1 \\
41-1\end{array}$ & $\begin{array}{r}2.7 \\
11.4 \\
20.4 \\
29.4 \\
38.4 \\
47.0 \\
59.5 \\
77.5 \\
91.0 \\
113.5 \\
131.5 \\
149.5 \\
167.6\end{array}$ & $\begin{array}{r}1.9 \\
44.9 \\
18.3 \\
33.2 \\
9.5 \\
22.1 \\
14.5 \\
16.3 \\
21.2 \\
7.2 \\
35.4 \\
30.1 \\
11.4\end{array}$ & $\begin{array}{r}-0.7 \\
0.9 \\
-0.9 \\
0.8 \\
-0.4 \\
0.0 \\
0.0 \\
0.9 \\
-0.1 \\
-4.3 \\
1.1 \\
-2.6 \\
-6.2\end{array}$ & $\begin{array}{l}0.3 \\
2.1 \\
0.4 \\
1.3 \\
0.6 \\
0.3 \\
0.5 \\
0.9 \\
1.1 \\
1.0 \\
0.7 \\
1.4 \\
1.4\end{array}$ & $\begin{array}{c}-22.7 \\
\text { n.d. } \\
-23.4 \\
-21.6 \\
-23.4 \\
-23.1 \\
-24.9 \\
-18.8 \\
-22.5 \\
-24.1 \\
-22.3 \\
-21.0 \\
-22.3\end{array}$ & $\begin{array}{r}\text { n.d. } \\
\text { n.d. } \\
24,200 \\
16,600 \\
12,100 \\
12,600 \\
5,780 \\
19,800 \\
10,100 \\
6,210 \\
10,100 \\
9,930 \\
3,390\end{array}$ & $\begin{array}{c}\text { n.d. } \\
-42.2 \\
-97.5 \\
-94.5 \\
-90.5 \\
-85.7 \\
-85.0 \\
-72.2 \\
-75.5 \\
-74.0 \\
-74.1 \\
-70.2 \\
\text { n.d. }\end{array}$ \\
\hline \multicolumn{8}{|l|}{ Hole $533 \mathrm{~A}$} \\
\hline $\begin{array}{l}4-2 \\
9-4 \\
11-5 \\
15-1 \\
17-6 \\
19-2 \\
21-4 \\
24-5 \\
26-3 \\
27-5 \\
29-3\end{array}$ & $\begin{array}{l}161.5 \\
209.0 \\
228.0 \\
266.0 \\
285.0 \\
304.0 \\
323.0 \\
351.3 \\
368.8 \\
380.0 \\
399.0\end{array}$ & $\begin{array}{r}6.9 \\
11.4 \\
17.6 \\
15.6 \\
16.6 \\
13.8 \\
20.6 \\
17.6 \\
21.9 \\
13.0 \\
16.2\end{array}$ & $\begin{array}{r}-5.0 \\
2.8 \\
2.0 \\
3.8 \\
2.0 \\
2.7 \\
4.3 \\
1.7 \\
-0.1 \\
1.5 \\
1.1\end{array}$ & $\begin{array}{l}1.4 \\
1.1 \\
2.4 \\
1.3 \\
1.9 \\
1.3 \\
1.6 \\
1.3 \\
1.3 \\
1.3 \\
1.2\end{array}$ & $\begin{array}{l}-21.6 \\
-22.7 \\
-21.9 \\
-21.3 \\
-22.3 \\
-22.3 \\
-22.2 \\
-22.1 \\
-22.3 \\
-22.2 \\
-22.7\end{array}$ & $\begin{array}{r}\text { n.d. } \\
4,550 \\
5,630 \\
6,150 \\
12,700 \\
2,140 \\
2,190 \\
2,720 \\
1,620 \\
1,240 \\
1,570\end{array}$ & $\begin{array}{c}\text { n.d. } \\
-65.3 \\
-66.9 \\
-62.7 \\
-64.5 \\
-64.0 \\
-61.8 \\
-62.6 \\
-63.1 \\
-66.0 \\
-64.9\end{array}$ \\
\hline
\end{tabular}

Note: n.d. $=$ not determined.

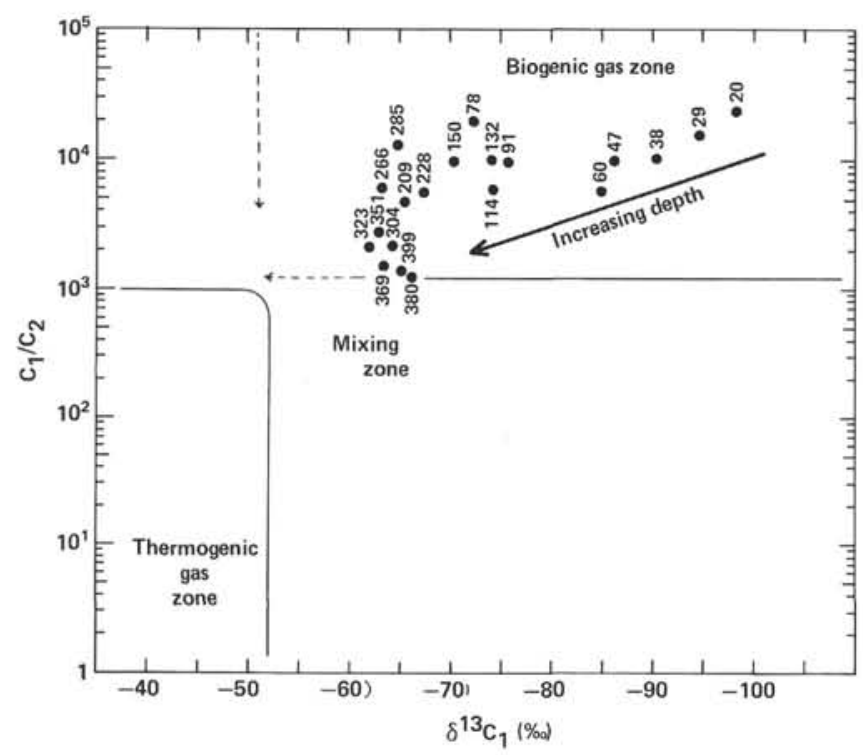

Figure 8. Molecular and isotope ratios of headspace gases plotted after Bernard et al. (1977).

imentary column. Below $150 \mathrm{~m}$ there is only a very gradual enrichment in ${ }^{13} \mathrm{C}$ with depth. There are several possible explanations for the increase toward heavier isotopes with depth in the sedimentary column. First, thermogenic $\mathrm{C}_{1}$ from deeper horizons could be moving up fracture or microfracture pathways. This would dilute the surface, isotopically light biogenic $\mathrm{C}_{1}$ with the deeper-sourced, isotopically heavier, thermogenic $\mathrm{C}_{1}$. Bernard (1978) has shown that diffusion from deeper thermogenic sources in fine-grained sediments cannot be the pathway for upward migration of gas beyond a few tens of meters. Therefore, if the $\delta^{13} C_{1}$ gradient observed is a result of upward migration from deeper thermogenic gas horizons, the gas has to be migrating by a mecha-

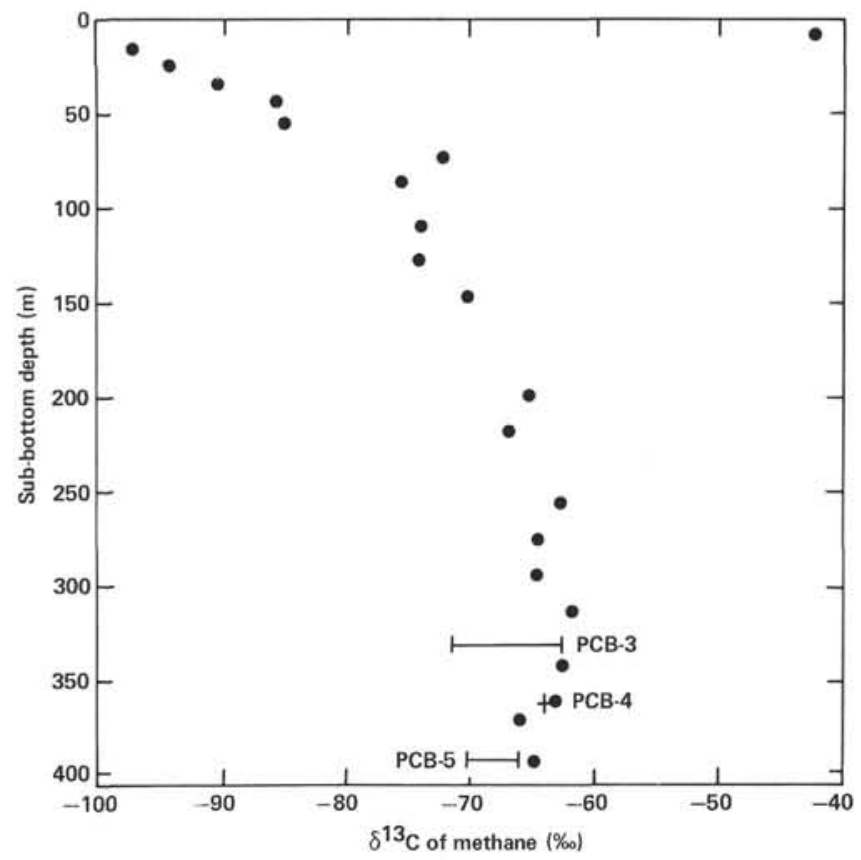

Figure 9. $\delta^{13} \mathrm{C}$ versus depth for headspace and $\mathrm{PCB}$ samples from Site 533 .

nism other than diffusion. The second possibility is that biogenic $\mathrm{C}_{1}$ production is occurring throughout the entire $400 \mathrm{~m}$ of sediment and that as the substrate used for $\mathrm{C}_{1}$ production becomes depleted in ${ }^{12} \mathrm{C}$ with depth, there is a resulting production of heavier $\mathrm{C}_{1}$. The last possibility is that there is low temperature $\left(<50^{\circ} \mathrm{C}\right)$ production of thermogenic gas in these relatively shallow sediments. This production would shift isotopic values to more positive ones as low temperature diagenesis increases with depth. The $C_{1}$ isotope curve observed in Figure 10 could result from a combination of these mechanisms.

The $-42.2 \%$ isotope value for $C_{1}$ observed at $11 \mathrm{~m}$ sub-bottom depth (Fig. 9) could result because of oxidation of $C_{1}$ in near-surface sediments. A possible explanation may be that there is partial consumption of $\mathrm{C}_{1}$ in the sulfate-containing sediments at this shallow depth, leaving isotopically heavy $C_{1}$ behind. Bernard (1978) observed a methane shift from $-80 \rightarrow-50 \%$ in the upper $1.5 \mathrm{~m}$ of a piston core from the Gulf of Mexico that was attributed to microorganisms consuming ${ }^{12} \mathrm{C}_{1}$ over ${ }^{13} \mathrm{C}_{1}$, thereby causing the residual methane to become isotopically heavier as it diffuses upward. Because the upper $15 \mathrm{~m}$ of the sediment column contains sulfate, methane consumption by sulfate-reducing bacteria may account for the $-42 \%$.

\section{Sediment Measurements}

Analyses of the major carbon-bearing species in Holes 533 and 533A sediments are presented in Table 4. Organic carbon increased from $0.3 \%$ at $2.7 \mathrm{~m}$ to $2.4 \%$ at $228 \mathrm{~m}$ sub-bottom, then decreased to about $1.2 \%$ near the bottom of the section. Although, the trend of organic carbon content is not uniform, there is a general increase with depth in the upper $200 \mathrm{~m}$. These organic car- 

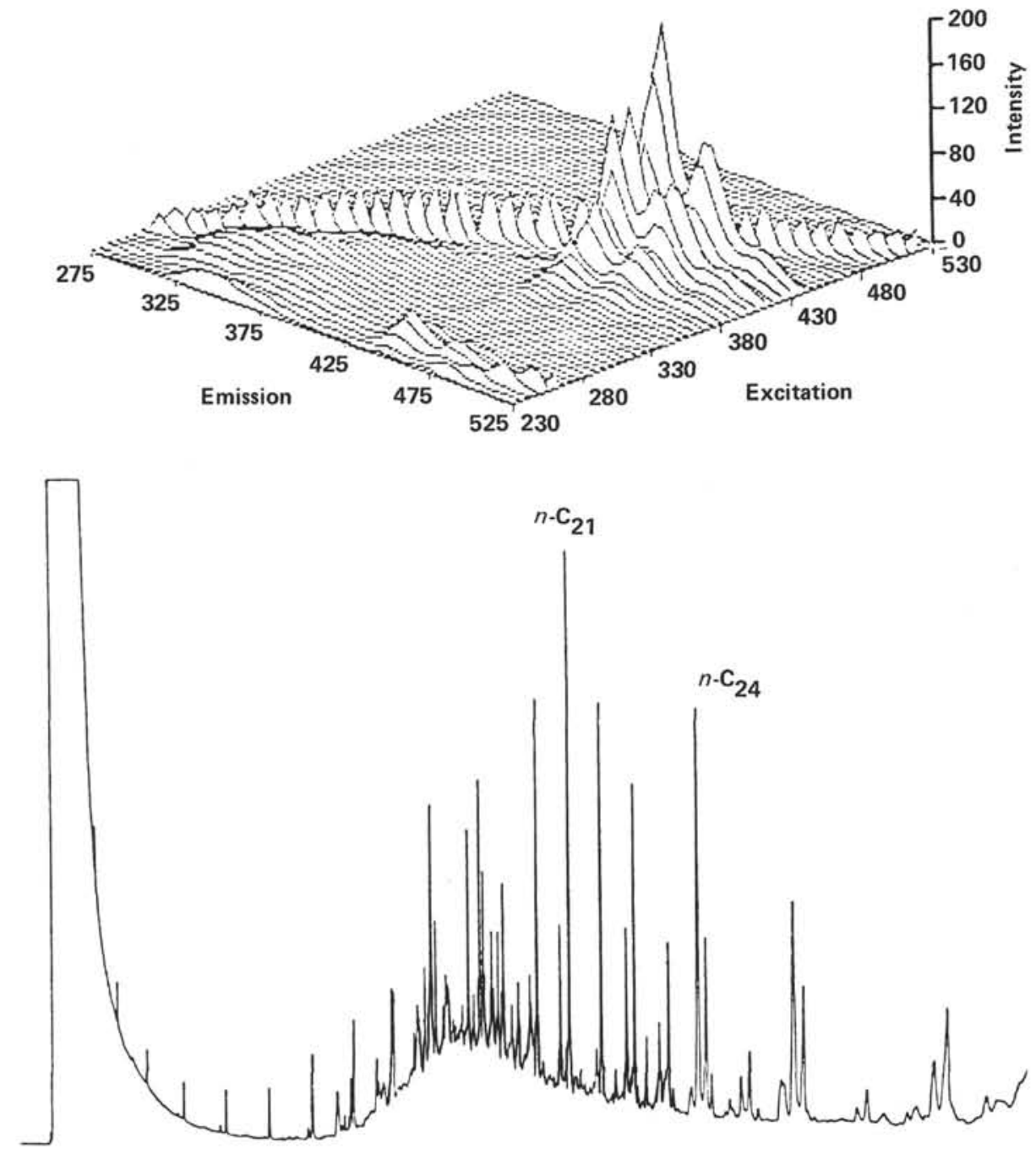

Figure 10. Total scanning fluorescence spectra and gas chromatograms from Section 533-27-5 (340.5 $\mathrm{m}$ sub-bottom depth). (Intensity maximum of 200 at an emission wavelength of $440 \mathrm{~nm}$ and an excitation wavelength of $434 \mathrm{~nm}$.)

bon values are no doubt the result of a high rate of sedimentation in the region, which tends to produce anaerobic sediments that aid in preserving organic matter. Claypool and Trelkeld (this volume) found that sulfate reduction was complete within the upper $14 \mathrm{~m}$ sub-bottom.

The calcium carbonate content of the section was quite variable (1.9-44.9\%). Although the lowest value was found at the surface, no discernible trends were recognizable with depth. Generally $\delta^{13} \mathrm{C}$-calcium carbonate and organic carbon were isotopically lighter in Hole 533 in comparison to Hole 533A.

In an attempt to identify further the source of hydrocarbons in Holes 533 and $533 \mathrm{~A}$, $\cong 5-\mathrm{g}$ aliquots of sediment were Soxhlet extracted for total scanning fluorescence and GC measurements. In all cases, indications of aromatic compounds were found similar to di- and trimethyl naphthalenes and perylene. Typical total scanning fluorescence spectra for sedimentary extracts are shown in Figures 10 and 11. The fluorescence patterns were generally of two types. Often only a perylene peak was evident (Fig. 10). This simple fluorescence pattern was typical of gas chromatograms exhibiting a strong quintuplet of peaks that eluted in the range of $n-\mathrm{C}_{25}$ to $n$ - $\mathrm{C}_{28}$. The dominant $n$-alkane was $n-\mathrm{C}_{21}$ or $n-\mathrm{C}_{22}$. The second fluorescence pattern contained a low end fluorescence signature in addition to the characteristic perylene peaks (Fig. 11). Fluorescence in this area is characteristic of naphthalene and alkylated analogues. The gas chromatograms for this type of fluorescence pattern showed a simple alkane distribution, although the quintuplet of peaks at $n-\mathrm{C}_{24}$ to $n-\mathrm{C}_{28}$ is still apparent. The gas chromatograms throughout the section were consistent. The upper $170 \mathrm{~m}$ were recovered from a hydraulic piston core that minimizes sample contamination. Thus contamination from drilling operations was felt to be negligible.

\section{SUMMARY}

Gas hydrates exist in Blake Outer Ridge sediments apparently in fine lenses within the semiconsolidated sediments. The only direct evidence of gas hydrates in these sediments comes from one specimen from an un- 

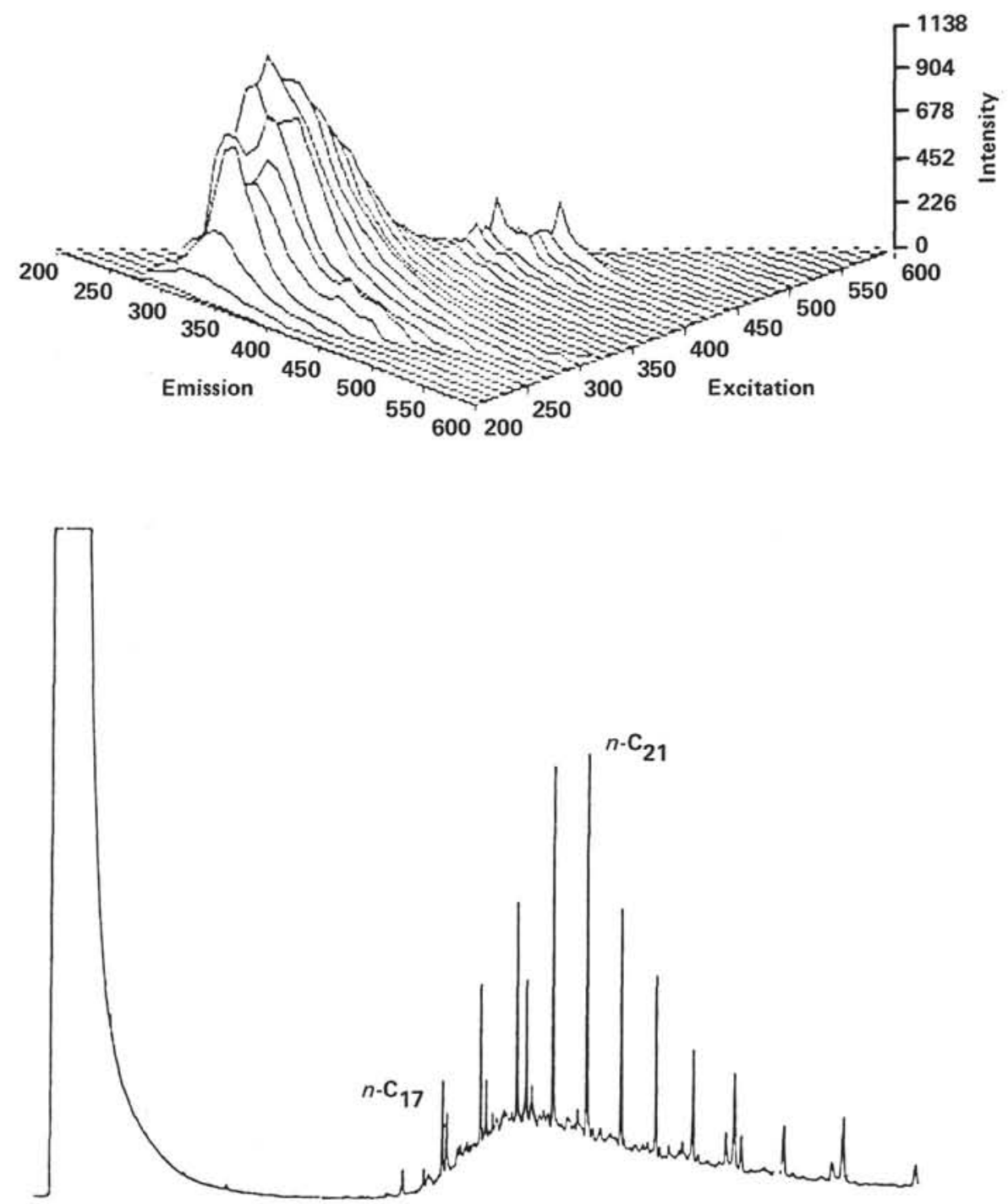

Figure 11. Total scanning fluorescence spectra and gas chromatograms from Section 533, 13-2 (42.9 $\mathrm{m}$ sub-bottom depth). (Intensity maximum of 1130 at an emission wavelength of 320 $\mathrm{nm}$ and an excitation wavelength of $280 \mathrm{~nm}$.)

pressurized core section in which icelike crystals of hydrates were visually observed and sampled. Molecular compositions and fluid:gas ratios for the icelike sample confirmed that it was a hydrate. Indirect evidence of hydrates in the sediment column came from two PCB retrievals in which the pressure decline curve indicated the "sawtooth" pattern characteristic of hydrate decomposition. However, much of the gas found in these sediments was apparently not in the hydrate form. Molecular and isotopic ratios of gas samples indicated a biogenic source for the methane gas. Trace amounts of higher-molecular-weight volatile organics were found in the sedimentary column as well.

\section{ACKNOWLEDGMENTS}

We thank the individuals of the Glomar Challenger for their help during the sampling procedures. Research support for this study was provided by Gas Research Institute Grant 50 81-363-0460 and Office of Naval Research Grant N00014-80-C-0113. This chapter benefited from critical reviews by Drs. William M. Sackett and Thomas Whelan, III.

\section{REFERENCES}

Bernard, B. B., 1978. Light hydrocarbons in marine sediments [Ph.D. dissert.]. Texas A\&M University, College Station, Texas.

Bernard, B. B., Brooks, J. M., and Sackett, W. M., 1977. A geochemical model for characterization of hydrocarbon gas sources in marine sediment. Proc. Offshore Technol. Conf., 2934:435-438. 1978. Light hydrocarbons in recent Texas continental shelf and slope sediments. J. Geophys. Res., 83:4053-4061.

Bolli, H. M., Ryan, W. B. F., et al., 1978. Init. Repts. DSDP, 40: Washington (U.S. Govt. Printing Office).

Brooks, J. M., Bernard, B. B., and Sackett, W. M., 1979. Characterization of gases in marine waters and sediments. In Watterson, J. R., and Theobold, P. K. (Eds.), Geochemical Exploration 1978: Rexdale, Ontario (The Association of Exploration Geochemists), pp. 337-346.

Brooks, J. M., Reid, D. F., and Bernard, B. B., 1981. Methane in the upper water column of the Northwestern Gulf of Mexico. J. Geophys. Res., 86:11029-11040.

Butler, L. D., and Burke, M. F., 1976. Chromatographic characterization of porous polymers for use as adsorbents in sampling columns. J. Chromatogr. Sci., 14:112-117.

Claypool, G. E., 1975. Manual on Pollution-Prevention and Safety (3rd ed.): JOIDES Journal, November. 
Davidson, D. W., 1973. Clathrate hydrates. In Franks, F. (Ed.), Water, A Comprehensive Treatise, 2, Water in Crystalline Hydrates, Aqueous Solutions of Simple Nonelectrolytes: New York (Plenum), pp. 115-234.

Davidson, D. W., El-Defrawy, M. K., Fuglem, M. O., and Judge, A. S., 1978. Natural gas hydrates in northern Canada. Proc. Int. Conf. Permafrost 3rd, 1:937-943.

Dillon, W. P., Grow, J. A., and Paull, C. K., 1980. Unconventional gas hydrate seals may trap gas off southeast U.S. Oil \& Gas J., 78 (1):124-130.

Edgar, N. T., Saunders, J. B., et al., 1973. Init. Repts. DSDP, 15: Washington (U.S. Govt. Printing Office).

Ewing, J. I., and Hollister, C. H., 1972. Regional aspects of deep sea drilling in the western North Atlantic. In Hollister, C. H., and Ewing, J. I., et al., Init. Repts. DSDP, 11: Washington (U.S. Govt. Printing Office), 951-973.

Hand, J. H., Katz, D. L., and Verma, V. K., 1974. Review of gas hydrates with implications for ocean sediments. In Kaplan, I. R. (Ed.), Natural Gases in Marine Sediments: New York (Plenum), pp. 179-194.

Heller, S. R., and Milne, G. W. A., 1978. EPA/NIH Mass Spectral Data Base. Nat. Stand. Ref. Data Ser., Nat. Bureau Stand., 63, Washington (U.S. Govt. Printing Office).

Hitchon, B. 1974. Occurrence of natural gas hydrates in sedimentary basins. In Kaplan, I. R. (Ed.), Natural Gases in Marine Sediments: New York (Plenum), pp. 195-225.

Hunt, J. M., 1975. Origin of gasoline range alkanes in the deep sea. Nature, 254:411-413.

1979. Petroleum Geochemistry and Geology: San Francisco (W. H. Freeman).

Hunt, J. M., and Whelan, J. K., 1978. Dissolved gases in Black Sea sediments. In Ross, D., Neprochnov, Y., et al., Init. Repts. DSDP, 42, Pt. 2: Washington (U.S. Govt. Printing Office), 661-666.

Kvenvolden, K. A., and Barnard, L. A., in press. Hydrates of natural gas in continental margins. Proc. Hedberg Conference: Tulsa (Am. Assoc. Pet. Geol.).

Kvenvolden, K. A., and McMenamin, M. A., 1980. Hydrates of natural gas: a review of their geologic occurrence. U.S. Geol. Surv. Circ., 825:1-11.

Lancelot, Y., and Ewing, J. I., 1972. Correlation of natural gas zonation and carbonate diagenesis in tertiary sediments from the northwest Atlantic . In Hollister, C. D., Ewing, J. I., et al., Init. Repts. DSDP, 11: Washington (U.S. Govt. Printing Office), 791-799.

Markl, R. G., Bryan, G. M., and Ewing, J. I., 1970. Structure of the Blake-Bahama Outer Ridge. J. Geophys. Res., 75:4539-4555.

Moore, J. C., Watkins, J. S., and Shipboard Scientific Party, 1979. Middle American Trench. Geotimes, 24(9):20-22.

Oremland, R. S., 1981. Microbial formation of ethane in anoxic estuarine sediments. Appl. Environ. Microbiol., 42:122-129.

Sackett, W. M., Nakaparksin, S., and Dalrymple, D., 1970. Carbon isotope effects in methane production by thermal cracking. In
Hobson, G. D., Speers, G. C. (Eds.), Advances in Organic Geochemistry, 1966: New York (Pergamon Press), pp. 37-53.

Sauer, T. C., Jr., 1978. Volatile liquid hydrocarbons in the marine environment [Ph.D. thesis]. Texas A\&M University, College Station.

Sauer, T. C., Jr., and Sackett, W. M., 1980. Gaseous and volatile hydrocarbons in marine environments with emphasis on the Gulf of Mexico. In Geyer, R. A. (Ed.), Marine Environmental Pollution, I. Hydrocarbons: New York (Elsevier/North-Holland), pp. 133-161.

Schwarzenbach, R. P., Bromund, R. H., Gschwend, P. M., and Zafiriou, O. C., 1979. Volatile organic compounds in coastal seawater: preliminary results. J. Org. Geochem., 1:45-61.

Shipley, T. H., Houston, M. H., Buffler, R. T., Shaub, F. J., McMillan, K. J., Ladd, J. W., and Worzel, J. L., 1979. Seismic evidence for widespread possible gas hydrate horizons on continental slopes and rises. Am. Assoc. Pet. Geol. Bull., 63:2204-2213.

von Huene, R., Aubouin, J., and Shipboard Scientific Party, 1980. Leg 67: the Deep Sea Drilling Project Mid-America Trench transect off Guatemal, Geol. Soc. Am. Bull., 91, Pt. 1:421-432.

Whelan, J. K., 1979. C 1 -C Hydrocarbons in Holes 397/397A, Leg 47A. In von Rad, U., Ryan, W. B. F., et al., Init. Repts. DSDP, 47, Pt. 1: Washington (U.S. Govt. Printing Office), 347-350.

Whelan, J. K., and Hunt, J. M., 1978. $\mathrm{C}_{1}-\mathrm{C}_{7}$ hydrocarbons in Holes 378A, 380/380A and 381. In Ross, D. A. Neprochnov, Y. P., et al., Init. Repts. DSDP, 42, Pt. 2: Washington (U.S. Govt. Printing Office), 673-677.

1980. $C_{1}-C_{7}$ volatile organic compounds in sediments from Deep Sea Drilling Project Legs 56 and 57, Japan Trench. In Scientific Party, Init. Repts. DSDP, 56, 57, Pt. 2: Washington (U.S. Govt. Printing Office), 1349-1354.

Whelan, J. K., and Sato, S., 1980. $C_{1}-C_{5}$ hydrocarbons from core gas pockets, Deep Sea Drilling Project Legs 56 and 57, Japan Trench transect. In Scientific Party, Init. Repts. DSDP, 56, 57, Pt. 2: Washington (U.S. Govt. Printing Office), 1335-1347.

Wiesenburg, D. A., in press. Determination of argon, oxygen, and nitrogen using activated charcoal. Anal. Chem.

Yefremova, A. G., and Zhizhchenko, B. P., 1974. Obnaruzheniye kristalligradov gazov osadkakh sovremennykh akvatoriy. "Occurrence of crystal-hydrates of gases in the sediments of modern marine basins." Dokl. Akad. Nauk SSSR, 214:1179-1181; Dokl. Akad. Nauk SSSR, Earth Sci. Sect. (Engl. Transl.), 214(1975): 219-220

Young, A., and McIver, R. D., 1977. Distribution of hydrocarbons between oils and associated fine-grained sedimentary rocks-physical chemistry applied to petroleum geochemistry, II. Bull. Am. Assoc. Pet. Geol., 61:1407-1436.

Date of Initial Receipt: April 22, 1982 